\title{
The Amorality of Profit: Transnational Corporations and Human Rights
}

\author{
By \\ Beth Stephens*
}

I.

INTRODUCTION

On the plane to California in March 2001, on my way to present a paper on corporate accountability and the Holocaust, I discovered a remarkably pertinent book review in that day's New York Times. ${ }^{1}$ The review addressed a recently published book on the role of IBM in Nazi Germany, IBM and the Holocaust, by Edwin Black. ${ }^{2}$ In his book, Black condemns IBM and its management for selling a revolutionary data management system to the Nazis. Black concludes that this system enabled Nazi Germany to organize information about the tens of millions of people under their control, a key tool without which they would not have been able to implement their brutally efficient extermination program. The reviewer, Richard Bernstein, challenges the conclusion that Germany needed IBM's technology. ${ }^{3}$ Even if Black's assertions were true, however, Bernstein offers a pointed critique of Black's underlying moral assumptions. IBM's conduct, according to Bernstein, merely demonstrated "the utter amorality of the profit motive and its indifference to consequences." "[M] any American companies did what I.B.M. did," Bernstein writes. 5 That is, "they refused to walk

* Associate Professor of Law, Rutgers-Camden Law School. My thanks to several generations of Rutgers-Camden research assistants: Christine Park, Mellany Alio, Danielle Buckley, Evelyn Cox, Kelly Lenahan, and Mark Morgan, as well as to the staff of the Rutgers-Camden law library. I should note that as a cooperating attorney with the Center for Constitutional Rights, I have assisted the plaintiffs in several of the human rights lawsuits against corporations discussed in this article.

1. Richard Bernstein, I.B.M.'s Sales to the Nazis: Assessing the Culpability, N.Y. TImES, March 7, 2001, at E8.

2. Edwin Black, IBM and the Holocaust: The Strategic Alliance between Nazi Germany and America's Most Powerful Corporation (2001).

3. Bernstein questions whether the Nazis in fact required IBM technology:

Is Mr. Black really correct in his assumption that without I.B.M.'s technology, which consisted mainly of punch cards and the machines to tabulate them, the Germans wouldn't have figured out a way to do what they did anyway? Would the country that devised the Messerschmitt and the V-2 missile have been unable to devise the necessary means to slaughter millions of victims without I.B.M. at its disposal?

Bernstein, supra note 1, at E8.

4. Id.

5. Id. 
away from the extraordinary profits obtainable from trading with a pariah state such as Nazi Germany."6 Such business decisions, he concludes, were reasonable, morally neutral choices.

Over the past decade, new revelations about corporate involvement in the Holocaust have sharpened our understanding of the extent to which even businesses that remained neutral towards Nazi Germany were able to profit from the Holocaust. Bernstein's perspective makes clear one ethical evaluation of such conduct: business as usual. At the same time, however, litigation against those corporations has demonstrated that the law takes a very different approach. Morally defensible or not, business as usual or not, if corporations are complicit in human rights violations, the victims of the abuses have a legal right to compensation from those corporations.

It is appropriate that the Holocaust serve as the trigger for a reassessment of corporations, morality and legal accountability. The horrors of World War II triggered the transformation of international human rights law. Over the fifty years since the Holocaust, the international community has recognized that governments can be held liable for abuses directed at both their own citizens and foreigners, during war and when at peace-and that individuals can be held accountable as well. Today, the abuses of the Holocaust are contributing to the development of new approaches to human rights accountability, this time focusing on corporate human rights violations and the line between the legally acceptable pursuit of profit and criminal or tortious behavior.

Profit-maximization, if not the only goal of all business activity, is certainly central to the endeavor. And the pursuit of profit is, by definition, an amoral goal-not necessarily immoral, but rather morally neutral. ${ }^{7}$ An individual or business will achieve the highest level of profit by weighing all decisions according to a self-serving economic scale. Large corporations magnify the consequences of the amoral profit motive. Multiple layers of control and ownership insulate individuals from a sense of responsibility for corporate actions. The enormous power of multinational corporations enables them to inflict greater harms, while their economic and political clout renders them difficult to regulate.

Corporate involvement in the Holocaust illustrates each of these points. Decisions as to whether to conduct business with the Nazi regime were often made in purely economic, amoral terms. Shareholders and managers were able to enjoy the profits generated from such business without directly confronting the human consequences of their business operations. Hundreds of thousands of people were harmed by corporate activities that spanned national borders and thus escaped regulation.

The role of corporations in the Holocaust also highlights an additional observation: Allowing corporate misdeeds to go unresolved compounds the problem dramatically. Fifty years later, attempts to compensate those harmed raise

6. Id. (quoting BLACK, supra note 2, at 232).

7. Unless, of course, one believes either that the pursuit of economic gain is by definition immoral or, at the other extreme, that making money is by itself a moral good. 
thorny questions, even beyond the factual issues generally present when attempting to determine the details of events that took place half a century ago. The use of slave labor by the Ford Motor Company, for example, arguably contributed to the vast expansion of that company over the following decades. ${ }^{8}$ But our modern judicial systems have difficulty calculating the value of that input to the company or to the millions of individual shareholders who might be asked to disgorge profits based in part on that labor. One of the many painful lessons we can draw from the Holocaust, then, is the need to settle corporate accounts in a timely fashion. ${ }^{9}$ By providing prompt compensation to those injured, we both offer justice to the victims of abuse and also prevent ill-gotten profits from becoming the foundation for future corporate growth.

With corporate abuses during the Holocaust as a background, I discuss in this article the development of corporate human rights law, looking both at the norms to which corporations must now conform and at the still weak efforts to enforce those norms. Corporate accountability for human rights abuses has received much attention over the past few years from governments, human rights organizations, business groups, and even the United Nations. Little has been written, however, about the relationship between corporate human rights norms and the legal structure of business organizations. My first goal in this essay is to strengthen the foundation of corporate human rights regulation by situating it within the extensive literature on the nature of the corporate entity and government power to impose limits on that entity.

My second goal is to propose an assertive approach to interpreting corporate human rights responsibilities. Both domestic governments and international organizations have danced around this topic, urging voluntary codes of conduct rather than seeking to impose binding rules of law. I argue that such circumspection is unfounded. Corporations are already bound by many core human rights norms. So-called voluntary codes that ask business entities to refrain from committing genocide or to avoid profiting from slave labor are weak concessions to the enormous economic and political power of multinational corporations.

Before beginning, a definitional parenthesis: I define the multinational corporation as any firm which "owns (in whole or in part), controls and manages income generating assets in more than one country." ${ }^{10}$ As Muchlinski explains, control is central to this definition-multinational corporations do not merely have a financial stake in foreign ventures but also exercise managerial control. ${ }^{11}$ This control enables a level of coordination among the various subparts that

8. See, e.g., Iwanowa v. Ford Motor Co., 67 F. Supp. 2d 424, 432-34 (D.N.J. 1999) (discussing allegations about Ford's use of slave labor and the impact of that labor on the company's profitability).

9. Current demands for compensation for slavery raise similar issues, over an even longer time period.

10. See Peter Muchlinski, Multinational Enterprises and the Law 12 (1995).

11. Id. 
transforms the multinational corporation from a mere network of independent entities into an entirely new business structure. ${ }^{12}$

I begin in part II with an overview of the human rights problems presented by multinational corporations, looking at modern human rights abuses as well as the Holocaust. Part III explains the regulatory challenge posed by transnational corporations, examining the historical development of the corporate structure and the disjuncture between modern multinational entities and the still largely independent domestic legal systems. Despite these challenges, governments clearly have the legal authority to regulate corporations, either through national or international legal regimes.

I discuss in part IV the foundation of this governmental power to regulate and demonstrate that such regulation is well-accepted in domestic legal systems around the world. In part V, I analyze the current state of the international law governing corporate human rights practices, concluding that core human rights norms apply to corporations as well as to states and individuals. Enforcement of these norms, however, remains "the Achilles' heel" of the system, as it does generally in the human rights arena. ${ }^{13}$ In part VI, I discuss this weakness and argue that international norms enforced through international mechanisms or coordinated domestic approaches are essential to the effective regulation of corporate human rights abuses.

A final caveat: My purpose in this article is not to enter the debate about whether multinational corporations have, as a whole, been good or bad for humanity. I do not address the benefits that this economic structure may or may not offer. My goal is to address the largely uncontrolled human rights danger posed by multinationals, and I do not pretend to offer a balanced assessment of multinational corporations. I do not accept that human rights abuses are the unavoidable price of economic development. To the contrary: our international and domestic legal systems have available the legal tools necessary to regulate multinational corporations and to deter and punish their human rights abuses.

12. International commentary uses various combinations of two sets of terms to refer to this entity: transnational/multinational and corporation/enterprise. The various combinations of these four terms are then abbreviated as MNCs, MNEs, TNCs and TNEs. A spirited literature ascribes content to the debate. See Muchlinski, supra note 10, at 12-15 (explaining history and content of the disagreements); Menno T. Kamminga \& Saman Zia-Zarifi, Liability of Multinational Corporations Under International Law: An Introduction, in LiabILITY of Multinational Corporations UNDER INTERNATIONAL LAw 1, 2-4 (Menno T. Kamminga \& Saman Zia-Zarifi eds., 2000) (comparing varying usages of multinational, transnational, corporation and enterprise) (hereinafter LIABILITY of Multinational Corporations].

"Multinational corporation" has a somewhat wider use and I will give it preference, while taking an expansive view of each of its terms. Thus, I include all cross-border corporate activities, whether they be "trans-" or "multi-" national. My use of the term "corporation" is similarly broad. In the interest of flexibility and readability, and in quotations from other works, I occasionally use the terms transnational and enterprise interchangeably with multinational and corporation.

13. See Beth Stephens, Book Review and Note: Remedies in International Human Rights Law, by Dinah Shelton, 95 AM. J. INT'L L. 257, 257 (2001) (discussing the absence of an effective enforcement system). 
II.

\section{The Corporate Human Rights Problem}

Corporate human rights abuses, of course, did not begin with World War II and the Holocaust. The earliest corporate-style multinational enterprises, the British and Dutch East India Companies, abused their extraordinary powers in Asia, Africa and the Americas to undermine local governments and exploit both human and natural resources. ${ }^{14}$ These abuses also triggered early consumer human rights protests, including seventeenth century British protests against the slave trade and boycotts in Massachusetts during the eighteenth and nineteenth centuries. $^{15}$

In this section, I discuss the harsh reality that corporations often profit from abusive behavior. From oppressive working conditions to slavery and even genocide, from pollution to environmental destruction, corporations are capable of extracting economic gain from harms inflicted on people and on the environment in which we live. I focus first on the Holocaust, during which thousands of corporations profited in varied ways, and then offer some modern examples. These extreme cases expose the degree to which the corporate pursuit of profit can lead to human rights abuses.

\section{A. The Holocaust}

Almost sixty years after World War II, the full extent to which corporations profited from the Holocaust is only now receiving widespread attention. The delayed investigations reflect both the power of corporations to mask their dealings and the difficulties created when justice is so long denied.

Most directly, financial corporations profited by retaining the assets of those killed by the Nazis. Banks and insurance companies pocketed the deposits of families who were exterminated or whose heirs were unaware of their relatives' accounts, as well as those who were unable to supply documentation to support their claims. ${ }^{16}$ In addition, banks profited from the mere fact that they

14. See, e.g., Teemu Ruskola, Conceptualizing Corporations and Kinship: Comparative Law and Development Theory in a Chinese Perspective, 52 STAN. L. Rev. 1599, 1677 (2000) (describing the British East India Company as "one of the most notorious corporations of all time," with a bitter legacy in China); Antony Anghie, Finding the Peripheries: Sovereignty and Colonialism in Nineteenth-century International Law, 40 HARV. INT'L L.J. 1, 37 (1999) (describing problems in the administration of colonies by corporate bodies as the "unsurprising" result of the fact that "the territories were administered simply for profit."); Bruce P. Frohnen \& Charles J. Reid, Jr., Diversity in Western Constitutionalism: Chartered Rights, Federated Structure, and Natural-law Reasoning in Burke's Theory of Empire, 29 MCGeorge L. Rev. 27, 34-46 (1997) (describing East India Company's rule in India as one of tyranny, despotism, corruption and bribery).

15. See Donald C. Dowling, Jr., The Multinational's Manifesto on Sweatshops, Trade/Labor Linkage, and Codes of Conduct, 8 Tulsa J. Comp. \& INT'L L. 27, 52 (2000) ("As far back as the seventeenth century, Britons were outraged at the East India Company's ventures in the slave trade."); Akhil Reed Amar, A State's Right, a Government's Wrong, WAsh. Post, Mar. 19, 2000, at B1 (Massachusetts citizens boycotted tea from the morally unattractive East India Company in the 18th century.).

16. See Michael J. Bazyler, Nuremberg in America: Litigating the Holocaust in United States Courts, 34 U. Rich. L. REv. 1, 31-39 (2000), for discussion of Holocaust claims against Swiss banks; $i d$. at 93-136, for claims against European insurance companies; $i d$. at 237-249, for claims 
were able to handle large accounts from Germany, investing the profits from assets stolen from Nazi victims as well as from goods produced by slave labor.

At the same time, companies exploited slave labor supplied to them by the German army. Recent investigations estimate that hundreds or even thousands of German companies benefited from the slave labor of eight to ten million people. ${ }^{17}$ In addition to paying little or nothing to the workers, the companies were often literally permitted to work their laborers to death. ${ }^{18}$ Major companies accused of profiting from slave labor include Ford, Siemens, Volkswagen, Daimler-Benz and BMW. ${ }^{19}$ According to claims filed against Ford, for example, the Ford affiliate in Germany operated with as much as half of its labor force composed of forced laborers. The company grew rapidly during the war years, emerging from the war as a powerful economic entity. ${ }^{20}$ Plaintiffs in the lawsuit sought disgorgement of profits accrued over more than fifty years, alleging that the U.S.-based Ford parent company profited from the rapid growth of its German subsidiary.

Thousands of corporations also did business with the German war industry. Deutsche Bank financed the construction of the Auschwitz concentration camp. ${ }^{21}$ Allianz, the second largest insurance company in the world, insured buildings and other facilities in the camp. ${ }^{22}$ Pharmaceutical companies supplied medication and other chemicals used in Nazi medical experiments. ${ }^{23}$ IBM supplied punch cards for Nazi record-keeping. ${ }^{24}$ Profits from these activities enriched successor corporations and have been distributed to investors throughout much of the Western world.

against non-Swiss banks. More than a dozen insurance companies have been accused of failing to honor policies issued before World War II. Id. at 101 .

17. Id. at 191-92.

18. The Nazi system included distinctions among workers of different "classes," regulating the amount of food and degree of abuse to which they would be subjected. Id. at $191 \mathrm{n} .784$. Some were intentionally worked to death:

The Jewish concentration camp workers were less than slaves. Slavemasters care for their human property and try to preserve it; it was the Nazi plan and intention that the Jews would be used up and then burned. The term "slave" is used in this [book] only because our vocabulary has no precise word to describe the lowly status of unpaid workers who are earmarked for destruction.

Benjamin B. Ferencz, Less than Slaves: Jewish Forced Labor and the Quest for CompensaTION at xvii (1979), quoted in Bazyler, supra note 16, at 191 n.784.

19. Companies and the Holocaust: Industrial Actions, ECONOMIST, Nov. 14, 1998, at 75, available in 1998 WL 11700614.

20. Iwanowa v. Ford Motor Co., 67 F. Supp.2d 424, 432-33 (D.N.J. 1999).

21. See Deutsche Bank Admits Auschwitz Role, IRISH TIMEs, Feb. 5, 1999, at 51, cited in Bazyler, supra note 16, at 237-38 n.1030.

22. See John Marks \& Jack Egan, Insuring Nazi Death Camps: History Catches Up with Another German Corporation, U.S. NEwS \& WoRLD REP., Feb. 22, 1999, at 52, cited in Bazyler, supra note 16, at 99 n.400.

23. Bazyler, supra note 16 , at 207 n.843, 249-55.

24. See Black, supra note 2. 


\section{B. Modern Day Abuses}

Corporate human rights abuses during the Holocaust raised issues unique in human history, as businesses profited from the systematic extermination of millions of people. Similar concerns, on a lesser scale, have been raised by corporate abuses during the past fifty years. Particularly egregious examples include the involvement of the United Fruit Company and ITT in overthrowing elected governments in Guatemala and Chile. ${ }^{25}$ Corporations have also participated on a massive scale in the exploitation of natural resources and corruption of national governments. ${ }^{26}$

Such conduct is not a relic of the past: corporate abuses today raise identical issues. In the pursuit of profit and often in partnership with repressive governments, corporations violate the rights to life, to health, to gainful employment, and to political participation. In offering a few examples, I focus on corporate abuses that have generated widely acknowledged violations over the past decade: security measures; sweatshops and other labor rights violations; and environmental harm.

When a business invests in a region with a repressive government and political unrest, it is often impossible to operate without becoming complicit in human rights abuses. Corporations, of course, have legitimate security concerns and a right to protect their employees and property. However, in some situations, it may be impossible to do so without participating in human rights abuses. At one extreme, corporate involvement may include paying such forces to suppress opposition to corporate activities. The Enron Corporation, for example, has been accused of collaborating with the Indian police to violently repress local residents opposed to a massive energy project. ${ }^{27}$ Royal Dutch Shell has been sued for alleged complicity in the executions of activists protesting the

25. See Stephen C. Schlesinger \& StePhen Kinzer, Bitter Frutt: The Untold Story of the American Coup in Guatemala (1982) (detailing role of United Fruit in overthrow of government of Guatemala); Multinational Corporations and United States Foreign Policy: Hearings before the Subcomm. on Multinational Corporations of the Senate Comm. on Foreign Relations, 94th Cong., 1st Sess. 381-86 (1975) (describing role of ITT in overthrow of Chilean government).

26. See, for example, Theodore Panayotou, Counting the Cost: Resource Degradation in the Developing World, in The Fletcher Forum OF World AfFaIRS 270, 271, 272 (1990), for discussions of the environmental impact of multinational activities; Louis Turner, Multinational CoMPANIES AND THE THIRD WORLD 11-12 (1973), for description of the impact of a 1968 corruption scandal on the government of Peru. Saman Zia-Zarifi explains why "resource extraction" corporations are "particularly prone to associate with egregious violators of human rights":

[R]esource extraction MNCs . . . have to dig for resources where they find them, typically in the developing world, and where the resource is one of the main sources of income for the government; all this in addition to the massive physical presence demanded for resource extraction work, including construction of large-scale infrastructure and intensive use of labor.... [W]ithout slandering the character and image of these corporations, their officers, shareholders, and employees, it is safe to say that sometimes resource extraction MNCs, like other MNCs, follow the path to profit around the world through rough moral terrain and get some of the dirt-if not blood-on their hands.

Saman Zia-Zarifi, Suing Multinational Corporations in the U.S. for Violating International Law, 4 UCLA J. INT'L L. \& ForeIGN AFF. 81, 82-83 (1999) (footnotes omitted).

27. See human Rights Watch, The Enron Corporation: Corporate Complicity in Human Rights Violations (1999); Amnesty International, India: The "Enron Project" in 
company's environmental and development policies in Nigeria. ${ }^{28}$ Human rights groups have also criticized British Petroleum for contracting with the Colombian armed forces despite reports of military human rights abuses from many sources, including the U.S. State Department. ${ }^{29}$ British Petroleum has acknowledged paying millions of dollars to the government to protect oil operations and has been criticized for taking no steps to ensure that human rights will be respected. ${ }^{30}$

A hotly contested lawsuit has charged the Unocal Corporation with complicity in human rights violations committed by the Burmese military government. A district court last year found that Unocal should not be held liable because it had not been actively involved in the abuses, a holding that is currently on appeal, but nevertheless found credible evidence of substantial corporate knowledge of the abuses:

Plaintiffs present[ed] evidence demonstrating that before joining the Project, Unocal knew that the [Burmese] military had a record of committing human rights abuses; that the Project hired the military to provide security for the Project, a military that forced villagers to work and entire villages to relocate for the benefit of the Project; that the military, while forcing villagers to work and relocate, committed numerous acts of violence; and that Unocal knew or should have known that the military did commit, was committing and would continue to commit these tortious acts. ${ }^{31}$

These examples highlight the problems raised not only when corporations directly commit human rights abuses, but also when they enter situations in which their activities foster or contribute to such abuses.

Such issues are also presented in the area of labor rights. Certain core labor rights have been recognized as entitled to international protection, including the rights to organize and to collective bargaining and the prohibitions of forced labor and certain kinds of child labor. ${ }^{32}$ Transnational corporations search out inexpensive locations to manufacture their products, often choosing countries with low wages and weak protection of labor rights. These practices often lead to denials of these basic rights. Investigations of working conditions in factories supplying goods to well-known brands such as Disney, Nike, and Levi Strauss have drawn attention to abuses including unpaid overtime, child labor, illegally low wages and dangerous working conditions. ${ }^{33}$

Maharashtra: Protests Suppressed in the Name of Development, AMNESTY INTERNATIONAL INDEX: ASA 20/31/97 (July 1997).

28. See summary of allegations in Wiwa v. Royal Dutch Petroleum Co., 226 F.3d 88 (2d Cir. 2000), cert. denied, 121 S.Ct. 1402 (2001).

29. Human Rights Watch, Columbia: Human Rights Concerns Raised by the Security Arrangements of Transnational Oil Companies (April 1998), at http://www.hrw.org/advocacy/corporations/columbia/Oilpat.htm.

30. Id.

31. Doe I v. Unocal Corp., 110 F. Supp. 2d 1294, 1306 (C.D. Cal. 2000).

32. See International Labor Organization, Declaration of Fundamental Principles and Rights at Work, June 18, 1998, II 2(a),(b),(c).

33. See generally No Sweat: Fashion, Free Trade, and the Rights of Garment Workers (Andrew Ross ed., 1997); Clean Clothes Campaign, at www.cleanclothes.org. 
Several lawsuits illustrate the environmental harm that transnationals can inflict when freed from the environmental regulations that apply in their home countries. Texaco in Ecuador, Freeport-McMaron in Indonesia, and Shell in Nigeria have all been accused of using devastating practices long banned in Europe and the United States. ${ }^{34}$ In Ecuador, for example, Texaco oil operations have reportedly spilled million gallons of oil and dumped billions of gallons of untreated toxic brine into the water and soil. ${ }^{35}$ One commentator has described Texaco as using "antiquated, pre-Love Canal technology" in Ecuador. ${ }^{36}$ In Indonesia, investigators have accused Freeport-McMaron of dumping hundreds of thousands of tons of toxic mine tailings into local waterways, destroying the local river, flooding surrounding forests, and polluting lakes and ground water. ${ }^{37}$ Shell's operations in Nigeria are reported to have devastated large tracts of land, producing fires that burn around the clock and soaking the groundwater with oil. $^{38}$

Current economic incentives are insufficient to trigger voluntary compliance with international human rights standards in the areas of physical integrity, labor rights or the environment. The legal system, however, is also at a disadvantage when regulating multinational actors, particularly those with the economic and political clout of multinational corporations. I look next at the difficulties of regulating multinational corporations, before turning to the options open to both national governments and the international community.

34. See, e.g., Wiwa v. Royal Dutch Petroleum Co., 226 F.3d 88 (2d Cir. 2000), cert. denied, 121 S.Ct. 1402 (2001) (Shell/Nigeria); Beanal v. Freeport-McMoran, Inc., 197 F.3d 161 (5th Cir. 1999) (Freeport-McMoran/Indonesia); Jota v. Texaco, Inc., 157 F.3d 153 (2d Cir. 1998) (Texaco/ Ecuador).

35. See Judith Kimerling, Disregarding Environmental Law: Petroleum Development in Protected Natural Areas and Indigenous Homelands in the Ecuadorian Amazon, 14 HASTINGs INT'L \& Comp. L. Rev. 849, $864-72$ (1991) (summarizing environmental abuses in Ecuador); Richard L. Herz, Litigating Environmental Abuses under the Alien Tort Claims Act: A Practical Assessment, 40 VA. J. INT'L L. 545, 547-48 (2000) (same).

36. Zia-Zarifi, supra note 26 , at 99 .

37. See Project Underground, Risky Business: The Grasberg Gold Mine 10, 14-18 (1998); Herz, supra note 35, at 548 .

38. See Ariadne K. Sacharoff, Note, Multinationals in Host Countries: Can They Be Held Liable Under the Alien Tort Claims Act for Human Rights Violations?, 23 BROOK. J. INT'L L. 927, 958-63 (1998) (describing of allegations of violations of environmental norms in Nigeria); see also Joshua P. Eaton, Note, The Nigerian Tragedy, Environmental Regulation of Transnational Corporations, and the Human Right to a Healthy Environment, 15 B.U. INT'L L.J. 261 (1997) (same).

See also Sudhir K. Chopra, Multinational Corporations in the Aftermath of Bhopal: The Need for a New Comprehensive Global Regime for Transnational Corporate Activity, 29 VAL. U. L. REV. 235 (1994) (detailing multinational corporate responsibility for a series of industrial disasters); Hari M. Osofsky, Note, Environmental Human Rights Under the Alien Tort Statute: Redress for Indigenous Victims of Multinational Corporations, 20 Suffolk Transnat'L L. Rev. 335 (1997) (allegations of corporate abuses in Indonesia and Ecuador); William A. Wines, Mark A. Buchanan \& Donald J. Smith, The Critical Need for Law Reform to Regulate the Abusive Practices of Transnational Corporations: The Illustrative Case of Boise Cascade Corporation in Mexico's Costa Grande and Elsewhere, 26 DENV. J. INT'L L. \& PoL'y 453 (1998) (alleging abuses by a logging company in Mexico, including environmental degradation and harassment of protestors). 
III.

The Regulatory Challenge

The modern multinational corporation has evolved over centuries, reaching its current form over the course of the past hundred years. The legal structures governing this modern entity, however, still reflect, to a large degree, the outmoded single-nation structure of the nineteenth century corporation. Corporations are multinational while legal systems are still largely national, creating a disconnect between international corporate structures and the law. A review of the history and focus of the transnational enterprise demonstrates that the multilayered, multinational division of labor and responsibility of the modern corporation, its singled-minded focus on economic gain, and its economic and political power all render multinational corporations a difficult regulatory target. Multinational corporations have long outgrown the legal structures that govern them, reaching a level of transnationality and economic power that exceeds domestic law's ability to impose basic human rights norms.

\section{A. The Rise of the Transnational Corporation}

The key characteristics of modern transnational business corporations developed piecemeal over the course of hundreds of years. This disjointed history explains the gap between the economic reality and the legal tools available to hold corporate groups accountable for their actions.

The concept of a corporation as a legal unit distinct from its owners traces back to Roman law. ${ }^{39}$ The first business corporations were chartered by the British Crown in the fifteenth century. These early business corporations followed the already settled corporate model of "a legal unit with its own legal rights and responsibilities, distinct from those of the individuals who constituted its members or shareholders ...."40 The core attributes of a corporation, present in these early models, included the right to sue and be sued, to contract, and to acquire and dispose of property. Shares in the corporation were transferable, and the corporation maintained a continuing existence regardless of its membership. ${ }^{41}$ Limited liability, now generally viewed as an additional core element of

39. See Phillip I. Blumberg, The Multinational Challenge to Corporation Law: The SEARCh for a New Corporate Personaltry 3-7 (1993), for a general history of the corporation. Blackstone credits Numa Pompilius (715-672 B.C.) with the development of the corporation as a means to dilute the power of two warring Roman factions by dividing them into smaller trade and professional groups. 1 William Blackstone, Commentaries on the Laws of ENGland 468-69, cited in Mark B. Baker, Private Codes of Corporate Conduct: Should the Fox Guard the Henhouse?, 24 U. Miami Inter-Am. L. Rev. 399, 406 n.41 (1993). Baker locates the earliest corporate structures in Rome, in approximately 700 B.C., then traces the development of the modern multinational corporation from fifteenth century merchant families with businesses throughout Europe, through seventeenth and eighteenth century merchant companies with royal charters and monopolies, to nineteenth century industries seeking raw materials from nations around the globe. Id. at 401-02.

40. BluMBERG, supra note 39 , at 4 .

41. Id. Additional attributes of the corporation at that time have not survived: a public purpose and monopoly powers. Id. at 5-7. 
the corporate form, became widespread only in the early nineteenth century in the U.S. and some fifty years later in England. ${ }^{42}$

Until well into the nineteenth century, corporations could be formed only by an act of the government-the king or Parliament in England, or the state legislatures in the United States. General statutes permitting incorporation through registration were not widespread until after the Civil War. ${ }^{43}$ The articles of incorporation approved by the government limited the corporation to a specific task. As one means to restrict the scope of activity of any one corporation, ownership of stock in another corporation was generally prohibited. This restriction persisted until the late nineteenth century: the generally accepted rule was that corporations could not own stock in other corporations. This limitation reflected in part a "deep suspicion and hostility" towards corporations and fear of corporate monopoly power. ${ }^{44}$ In the words of a Georgia court, "It has ever been considered the very highest public policy to keep a strict watch upon corporations, to confine them within their appointed bounds and especially to guard against the accumulation of large interests under their control.,45

Despite these restrictions, large multinational enterprises began to develop in the second half of the nineteenth century, as individual corporations expanded their operations. ${ }^{46}$ U.S. firms quickly expanded their manufacturing and distribution networks around the world. Muchlinski describes the growth of the American Singer Sewing Company as "the first true manufacturing" multinational enterprise. ${ }^{47}$ Over the course of the second half of the nineteenth century, the Singer Company sold finished machines in Europe; it began to assemble sewing machines in Europe from parts manufactured in the United States; and in 1882 , it built a factory in Glasgow to manufacture machines from local parts. ${ }^{48}$ During the same time period, during the last years of the nineteenth century, corporations based in England, Germany and other European countries began to expand their direct investments in foreign nations. ${ }^{49}$

The rise of the modern transnational corporation in the United States traces to the late 1880s. The legislature of New Jersey, in an effort to attract corporate licensing fees, liberalized corporate regulatory statutes, authorizing businesses incorporated in New Jersey to own stock in any other corporation. ${ }^{50}$ This New Jersey statute represented a major turning point in the history of U.S. business. As the other states followed suit, "Corporate groups soon grew to occupy a

42. Id. at 7-19. Moreover, exceptions to limited liability continued well into the twentieth century, including provisions for double and triple indemnity, and pro rata liability in California. Id.

43. Id. at 22. The Constitutional Convention overwhelmingly rejected a proposal to grant the power of incorporation to the new Congress. Id. at 31.

44. Id. at 52-54. "United States colonists were suspicious of corporations, viewing them as representing "the privileged society against which the settlers were rebelling." Baker, supra note 39, at 407, citing I. Maurice Wormser, Frankenstein, Incorporated 28 (1931).

45. Central R.R. v. Collins, 40 Ga. 582, 625, 630 (1869).

46. Muchlinski, supra note 10 , at $20-21$.

47. Id. at 21 .

48. Id.

49. Id. at 21-22.

50. Blumberg, supra note 39 , at 56 . 
commanding role in American industry and eventually in the world economy as well." 51

The protections of limited liability were transferred immediately to these new corporate groups-without any recognition of the distinction between the limited liability of individual shareholders and that of a collective enterprise composed of parent and subsidiary companies engaged in a common enterprise. ${ }^{52}$ Blumberg has pointed out the illogic of this extension of limited liability protections to the components of a corporate group:

It overlooked the fact that the parent corporation and its subsidiaries were collectively conducting a common enterprise, that the business had been fragmented among the component companies of the group, and that limited liability-a doctrine designed to protect investors in an enterprise, not the enterprise itselfwould be extended to protect each fragment of the business from liability for the obligations of all the other fragments. ${ }^{33}$

Nevertheless, limited liability within the corporate group remains the norm today.

With this new authority to own stock in other corporations, multinational corporate groups grew rapidly during the years leading up to the first World War, followed by a slow period between the two World Wars, and resumption of rapid expansion after World War II. ${ }^{54}$ Post-World War II multinational growth followed a new style. Pre-World War I, international trade had been dominated by imports of raw materials and agricultural products from the developing countries of the South to meet the needs of manufacturers and consumers in the industrialized North. ${ }^{55}$ After World War II, the truly modern multinational corporation came to dominate, with integrated production across borders, and goods and services flowing in multiple directions. ${ }^{56}$ This modern model has proven difficult to regulate with the legal tools available to the governments of sovereign states.

\section{B. The Difficulty of Regulating Transnational Corporations: Corporate Economic, Political and Legal Power}

Multinational corporations have proven to be remarkably efficient economic entities, "formidably effective and swift machine[s]," capable through their coordinated operations of far outperforming smaller scale, national business models. ${ }^{57}$ The multinationals exploit to great effect their ability to coordinate operations and to trade and invest internally, seeking the greatest return for

51. Id. at 58 .

52. Id. at 58-59.

53. Id. at 59 .

54. U.S. companies dominated this expansion until the 1960 s, when the economies of Europe and Japan recovered from the devastation of the war. The past decade has seen the entry of both the former Socialist nations and developing countries onto the international trade and investment stage. MUCHLiNSKI, supra note 10 , at 26-32.

55. Id. at 22 .

56. Id. at 26.

57. Detlev F. Vagts, The Multinational Enterprise: A New Challenge for Transnational Law, 83 HaRv. L. REv. 739, 756 (1970). 
the group as a whole. In short, "multinational groups pursue a policy of group profit maximization in which the interests of the individual constituent members of the group are subordinated to the interests of the parent, that is, the group as a whole." 58

The tremendous growth of multinational corporations has raised new accountability dilemmas. Corporations have grown to a level of economic power that dwarfs most nation-states. General Motors, for example, is larger than the national economies of all but seven countries. ${ }^{59}$ The largest fifteen corporations have revenues greater than all but thirteen nations. ${ }^{60}$ And the trend is toward greater corporate dominance: a comparison of figures from 1991 and 2000 shows a dramatic change over nine years. In 1991, nineteen countries had revenues greater than General Motors, compared to only seven today; similarly, in 1991, three corporations were among the top twenty-eight economic entities, compared to fifteen today. ${ }^{61}$

Concerns about corporate economic power are not new: analysts have decried growing corporate power as far back as the Dutch East India Corporation. ${ }^{62}$ President Lincoln expressed concern about the growth of corporate power following the Civil War. ${ }^{63}$ On the international stage, corporate dominance over the economy became an issue of global concern in the $1960 \mathrm{~s} .{ }^{64}$ This pattern has accelerated over the past decade, as the socialist economies collapsed

58. Blumberg, supra, note 39 , at 139 . Vagts cautions against exaggeration of the internal consistency of corporate decision-making, noting that corporate "structures house considerable tensions between different levels of management, between home offices and branches abroad, between line and staff," so that "one must consider MNE activities as the end-product of a coalition of individuals pursuing somewhat different goals and coordinated only to a limited degree toward the achievement of a common purpose." Vagts, supra note 57, at 753. Despite this caution, however, he concludes that the multinational corporation is "basically a coherent organization with a narrow range of economic motivations," capable of efficient, coordinated economic activity. Id. at 756.

59. Only the economies of the United States, Germany, Italy, the United Kingdom, Japan, France and the Netherlands are larger than General Motors. See Global Policy Forum, Comparison of Revenues Among States and TNCs, at http://www.globalpolicy.org/socecon/tncstat2.htm (last visited May 23, 2001).

60. Id.

61. Compare id. with Nations $v$. Corporations, at http://www.ratical.com/corporations/NvC. html (last visited May 23, 2001).

62. See sources cited supra, note $\mathbf{1 4}$ (noting contemporary concerns about Dutch East India Company and its powers).

63. Lincoln wrote in a letter in 1864 :

I see in the near future a crisis approaching that unnerves me and causes me to tremble for the safety of my country. As a result of the war, corporations have been enthroned and an era of corruption in high places will follow, and the money power of the country will endeavor to prolong its reign by working upon the prejudices of the people until all wealth is aggregated in a few hands and the Republic is destroyed. I feel at this moment more anxiety for the safety of my country than ever before, even in the midst of war. God grant that my suspicions may prove groundless.

Letter from Lincoln to Col. William F. Elkins, Nov. 21, 1864, in THE LinCOLN ENCYCLOPEDIA 40 (Archer H. Shaw ed., 1950) (quoting Emanuel Hertz, 2 Abraham Lincoln: A New Portratt 954 (1931)).

64. "That the world's largest multinational corporations ... are more powerful and influential than many States has been a cliché since the 1960s." Menno T. Kamminga, Holding Multinational Corporations Accountable for Human Rights Abuses: A Challenge for the EC, in THE EU AND Human Rights 553, 553 (Philip Alston ed., 1999). 
and opened up to capitalist investment, and as developed nations reduced regulation of international trade and investment, and pressured developing nations to do the same. "No longer is the control of the potentially negative impacts of TNCs the major issue; rather it is how best to reintegrate developing countries into the global economy in a manner that ensures inflows of new investment capital." 65 With the fall of the Soviet bloc, economic deregulation has become the mantra of the new millennium. International trade agreements have pushed the free trade model upon even the more reluctant national governments. "States once critical of TNCs now find themselves competing for the benefits of foreign direct investment from multinational companies." 66

As both cause and effect of growing corporate economic power, the international and domestic political systems have increasingly relinquished their control over business. Economic power carries with it a growing political clout. Corporations play influential direct and indirect roles in negotiations over issues ranging from trade agreements to international patent protections to national and international economic policy. ${ }^{67}$ This political power is in part a recognition of the economic advantages of the multinational corporate model. But it also reflects corporate power advantages that put governments at a disadvantage. Governments themselves are coalitions, representing varying interests, and may have difficulty submerging those differences into a common policy. ${ }^{68}$ "MNE's [Multi-National Enterprises] in the past often have used their bargaining skills, their clearly conceived purposes and their overall experience to outdo naive and divided governments." 69

The very strengths of transnationals render them difficult regulatory targets. As corporate power becomes increasingly international and increasingly disassociated from the nation-state, regulation becomes more difficult. "The fact that they have multiple production facilities means that TNCs can evade state power and the constraints of national regulatory schemes by moving their operations between their different facilities around the world." ${ }^{\text {"0 }}$ Regulatory schemes are largely domestic, based upon national laws, administrative bodies and judicial systems, while transnationals operate across borders. ${ }^{71}$ Over thirty years ago, Professor Vagts pointed out that "the present legal framework has no comfortable, tidy receptacle for such an institution," producing a tension between the legal theory of independent corporate units, each "operating as a native within the country of its incorporation," and the reality of the "economic interdepen-

65. MUCHLINSKI, supra note 10 , at 596 .

66. Barbara A. Frey, The Legal and Ethical Responsibilities of Transnational Corporations in the Protection of International Human Rights, 6 MinN. J. Global Trade 153, 160 (1997).

67. See generally Vivien A. Schmidt, The New World Order, Incorporated: The Rise of Business and the Decline of the Nation State, in 124 DaEDalus 75 (1995).

68. Vagts, supra note 57, at 757.

69. Id. at 780 .

70. Claudio Grossman \& Daniel D. Bradlow, Are We Being Propelled Towards a PeopleCentered Transnational Legal Order?, 9 AM. U. J. INT'L L. \& PoL'y 1, 8 (1993).

71. "In the modern world of transnational corporations, the economic actor is typically the corporate group; however, the law continues to focus on each component company, rather than on the group, as the legal actor." BLUMBERG, supra note 39, at 205. 
dence" of the multinational corporation. ${ }^{72}$ More recently, even George Soros has decried the lack of a global system capable of regulating global capitalism. ${ }^{73}$

In addition, the recent trend toward decreasing government control over international commerce has led to the weakening of ties between transnational corporations and particular states. The state of incorporation may be nothing more than a convenient location chosen for tax and other regulatory advantages. " ${ }^{74}$ "One important effect of these developments is that TNCs have become 'de-nationalized' in the sense that they view the world, rather than their home or host states, as their base of operations." 75 With multinational sources of financing, operations, and international joint ventures, "corporations are part of a 'global web' that increasingly defies categorization by national origin."76 The dispersed corporate form permits corporations to establish legally independent entities around the world, a multinationality that transforms into statelessness.

However, states cannot regulate transnational corporations effectively without addressing all aspects of the operation. "From the viewpoint of effective economic regulation, it is not merely appropriate, it is essential that the legal structure match the economic structure of the enterprise subject to the regulatory system."77 Otherwise, multinationals shift capital and goods to avoid regulation, taxation, capital repatriation rules, and currency exchange controls, and to resist union demands. ${ }^{78}$ Prevention of corporate evasion of regulatory standards requires international consensus on the norms applicable to corporations. Enforcement of regulations requires coordinated enforcement mechanisms, whether through international systems or through coordinated domestic structures. I lay the foundation for my discussion of international norms and coordinated enforcement mechanisms by examining the state's power to regulate transnational corporations.

72. Vagts, supra note $\mathbf{5 7}$, at $\mathbf{7 4 0 , 7 4 3 .}$

73. George Soros, Towards a Global Open Society, 1/1/98 AtLantic Monthly 20 (1998) ("[T]he capacity of the state to look after the welfare of its citizens has been severely impaired by the globalization of the capitalist system ....").

74. Fleur Johns, The Invisibility of the Transnational Corporation: An Analysis of International Law and Legal Theory, 19 MelBouRNE UNrv. L. Rev. 893, 895-96 (1994). ("[S]election of a state of incorporation may be a matter of mere convenience-a decision made at a particular time for tax or other reasons. The fact that this decision may have lasting significance at international law seems therefore ludicrous.").

75. Grossman \& Bradlow, supra note 70 , at 8 .

76. Schmidt, supra note 67, at 79, citing RoBert ReICH, THE WORK OF Nations (Knopf 1991).

77. BLUMBERG, supra note 39 , at 201. "The reality of the matter is that effective regulation of corporate groups or their activities inevitably requires control of all the components participating in the enterprise." Id. at 200-01. "While the economic forms of enterprise organization have evolved in the direction of multicorporate structures, the legal forms of its organization have remained stuck to a statutory model designed and conceived exclusively for the case of single corporate enterprises." Jose Engracia Antunes, The Liability of Polycorporate Enterprises, 13 CoNN. J. INT'L L. 197, 207 (1999).

78. BlumberG, supra note 39 , at $139-40$. 
IV.

\section{The State's Power to Regulate}

Despite centuries of development, and the fact that corporations support the world economy, economists, lawyers, political theorists and philosophers continue to debate the essential definition of the corporation. Under any of the myriad of conflicting views, however, a government has the right and power to regulate corporate firms. Moreover, governments of every variety have done so, holding corporations accountable for their actions through some combination of criminal, civil or administrative sanctions. This section will first demonstrate that whatever their nature and whatever their inherent social responsibilities, governments have the legal authority to hold corporations liable for harms their operations inflict. Next, a comparative review of disparate legal systems will demonstrate that states assert that right through varied legal procedures.

\section{A. The Inherent Nature of the Corporation: Whatever It Is, It Can Be Held Accountable}

Academics and practitioners from several disciplines have produced a vast literature debating the nature of the corporation. The fault lines of this debate reflect several heated disputes about the nature of the corporation, its formation, and its social obligations. Under any of these views, however, government has the right and power to restrict corporate behavior. Without a doubt, states can forbid corporate conduct constituting human rights abuses, such as physical harm, denials of basic labor rights, and harm to the environment, and can hold corporations liable for violations of these basic rights.

\section{The Corporate Nature Debate and Accountability for Human Rights Violations}

Debate over the nature of the corporation as a legal and economic institution has continued for centuries. Ninety years ago, the literature on the controversy was described as of "appalling size,"79 and it has grown apace during the ensuing decades. ${ }^{80}$ One product of this multitude of analyses is disagreement even about how to classify the varied theories. Bratton lists three sets of "recurring questions" that are the subject of the inquiry. ${ }^{81}$ The first set of questions examines the corporation's "being"-is the corporation a construct of people's minds or a real thing with a separate existence? A second and related line of questions examines the distinction between the corporate being, whatever it is, and "the aggregate of separate individuals and transactions in and around it,"82 the "entity" or "aggregate" debate. Third is what Bratton terms a "political ver-

79. Arthur W. Machen, Jr., Corporate Personality, 24 HaRv. L. Rev. 253, 254 n.3 (1911).

80. See William W. Bratton, The New Economic Theory of the Firm: Critical Perspectives From History, 41 STAN. L. REV. 1471 (1989), for a thorough analysis and history of the debates.

81. Id. at 1474-75.

82. Id. at 1475 . 
sion" of these questions, which asks whether the corporation is a creature formed by the state or rather the sum of contractual arrangements by individuals.

Working within a similar framework, Blumberg summarizes three historical answers to these questions. ${ }^{83}$ The earliest view of corporate nature, reflecting a time when corporations could only be formed through a special legislative decree, saw the corporation as an artificial person, created by the legislature, not by individuals. Chief Justice Marshall articulated this view of the firm as the artificial creation of law, existing only by virtue of government's permission:

A corporation is an artificial being, invisible, intangible, and existing only in contemplation of law. Being the mere creature of law, it possesses only those properties which the charter of its creation confers upon it, either expressly, or as incidental to its very existence. ${ }^{84}$

Under this view, the corporation has only those rights and obligations attributed to it by the enacting legislation. ${ }^{85}$

A second view of the corporation describes it as primarily an association of individuals contracting with each other to form the corporation. The Supreme Court employed this view as a means to explain the attribution of constitutional rights to corporations:

Private corporations are, it is true, artificial persons, but ... they consist of aggregations of individuals united for some legitimate business .... It would be a most singular result if a constitutional provision intended for the protection of every person against partial and discriminating legislation by the states, should cease to exert such protection the moment the person becomes a member of a corporation. 86

The corporation thus claims certain rights to protect the rights of the individuals of whom it is composed. ${ }^{87}$

A third view, which Professor Blumberg describes as a "strong" version of the entity theory, defines the corporation as an organic being, with independent legal rights that go beyond both those of its shareholders and those granted by the government. ${ }^{88}$

Whether the corporation is a creature created by law, one arising out of a web of individual contractual agreements, or a distinct legal being, it is subject to state regulation. Indeed, as John Dewey pointed out many decades ago, the debate about the inherent nature of the corporation is essentially no different than a debate about what rights and obligations society will choose to impose upon it. ${ }^{89}$ " "The corporation is . . a right-and-duty-bearing unit," with those

83. Phillip I. Blumberg, The Corporate Entity in an Era of Multinational Corporations, 15 Del. J. CoRP. L. 283, 291-99 (1990).

84. Trustees of Dartmouth College v. Woodward, 17 U.S. (4 Wheat.) 518,636 (1819).

85. Blumberg, The Corporate Entity, supra note 83, at 293.

86. The Railroad Tax Cases, 13 F. 722, 743-44 (C.C.D. Cal. 1882), writ of error dismissed as moot sub nom. See also San Mateo County v. Southern Pac. R.R., 116 U.S. 138 (1885); Santa Clara v. Southern Pac. R.R., 18 F. 385 (C.C.D. Cal. 1883), aff'd, 118 U.S. 394 (1886).

87. Blumberg, The Corporate Entity, supra note 83, at 293-95.

88. Id. at 295.

89. See John Dewey, The Historic Background of Corporate Legal Personality, 35 YALE L.J. 655 (1926). 
rights and duties which the law ascribes to it. ${ }^{90}$ The imposition of duties upon the corporate unit applies either to the corporation as an entity or to the individuals who contract to establish the corporation. Either way, the state can impose limits on corporate behavior, including accountability for harms caused to others.

To be sure, proponents of the view that the corporation is no more than a set of contractual relations have argued against government regulation, asserting that individuals left to negotiate contracts will better achieve their own and society's goals. 'Since their firm 'is contract,' and since private actors do a better job at making contracts than do government officials, they see little constructive role for public policy." 91 This policy argument, however, does not challenge the underlying governmental authority to regulate the corporation. The contracts that form the basis of a corporation under this theory are no more immune from government oversight than individual agreements. Government can impose civil and criminal liability on those who contract to violate the law, regardless of whether or not the contract is formed in a corporate context. The state may prohibit individuals from committing physical abuses, labor law violations, and environmental harm; under any of these corporate theories, the state may also prohibit corporations from committing these offenses.

\section{Corporate Amorality}

Are multinational corporations amoral by definition? In the vast literature on this issue, vigorous calls for corporate social responsibility are countered by equally spirited cries that business enterprises are, by definition, created only to make a profit. ${ }^{92}$ Neither view, however, challenges government's authority to impose regulations on corporations.

In a now-famous essay, Milton Friedman insisted that "the social responsibility of business is to increase its profits." 93 William Safire picked up the refrain decades later, railing against "new socialists" who sought to impose social responsibilities on corporations. ${ }^{94}$ Safire argues that his model of unregulated business operations need not entail disregard for the social consequences of business decisions. He insists that corporate executives inevitably adopt socially responsible policies out of self interest:

Capitalism's defenders know that only stupidly shortsighted executives overlook the need for a loyal, motivated work force; we also know that good community relations help attract the best managers and innovators to a company. And easing the shock of necessary belt-tightening on workers who are not producing is "good P.R.," which makes business sense-provided it does not squander assets on ego-

90. Id. at 656 (quoting 3 Martland, Collected Papers 307 (1911)).

91. Bratton, supra note 80 , at 1482 (footnote omitted).

92. See Ethical Theory and Business (Tom L. Beauchamp \& Norman E. Bowie eds., 5th ed. 1997), for a collection of essays giving an overview of the issues.

93. Milton Friedman, The Social Responsibility of Business is to Increase Its Profits, N.Y. Times Magazine, Sept. 13, 1970, reprinted in Ethical Theory and Business, supra note 92, at 56.

94. William Safire, The New Socialism, N.Y. Times, Feb. 26, 1996, p. A13. 
satisfying do-gooding or becoming the new delivery system for politicians' largesse.

What are the primary "social" responsibilities of a corporation? To serve its owners by returning a profit and its community by paying taxes; to earn the allegiance of customers by delivering value, and to provide a secure future for employees who help it succeed in the marketplace. ${ }^{95}$

However, Safire's premise is questionable even within the United States, with its democratic political system and active media. As Safire describes the motivations leading to socially responsible behavior, profit-based incentives only deter abusive corporate behavior if such behavior leads to "bad P.R." The various interest groups Safire identifies-shareholders, management, employees-have multiple goals, but their self interest is not necessarily advanced by adopting protections against corporate human rights violations.

Moreover, these business-based motives are of no relevance in repressive societies. If the media are unable to report on abusive behavior, there will be no public relations consequences of corporate bad acts. If government leaders share in the inflated profits generated by abusive behavior, they will have no incentive to enforce even the most basic norms. As Douglas Cassel suggests, theories of self-regulating corporate structures work, if at all, only in democratic systems. 96 "In most countries, governments have limited power or resources to do good." 97 The profit motive will inevitably exert pressure against responsibility, creating incentives to cut corners, and to commit abuses. If this is the case even in a democratic society, it is much more the case in a repressive system, where the citizenry has no means by which to force corporate accountability.

The issue of whether businesses are defined as purely profit-seeking or as obligated to respond to certain societal needs is, fundamentally, a question to be decided by society as a whole. Debates about the social obligations of the corporation are "hopelessly circular" because "[o]ur beliefs about what are proper concerns of the business community are themselves social constructs, and have evolved significantly over time in tandem with broader changes in the social and political environment."98 As proponents of the amorality of profit disengage corporate policy from social concerns, they merely emphasize the role of government in setting the boundaries of acceptable corporate behavior:

[T]o the extent that this argument asserts that it is the role of government to fashion and implement policy -in this case human rights policy-it also necessarily concedes to government the right to further specific policies by, inter alia, regulating the practices of U.S. corporations. Examples of such regulation, from legislation restricting companies' ability to discriminate or pollute at home, to laws prohibiting corrupt practices by corporations abroad, are too numerous to leave any room for doubting the legitimacy of government efforts to advance social policies in part by regulating corporate behavior. ${ }^{99}$

95. Id.

96. Douglas Cassel, Corporate Initiatives: A Second Human Rights Revolution?, 19 FordHAM INT'L L. J. 1963, 1978-80 (1996).

97. Id. at 1980.

98. Diane F. Orentlicher \& Timothy A. Gelatt, Public Law, Private Actors: The Impact of Human Rights on Business Investors in China, 14 Nw. J. INT'L L. \& Bus. 66, 96 n.83 (1993).

99. Id. 
Society has the authority to regulate corporate behavior, by defining the terms of the corporate entity and its relationship with the surrounding society. Such has been the conclusion of domestic legal and political systems around the world, a comparative perspective to which I now turn.

\section{B. A Comparative View: Corporate Accountability Across Legal Systems}

All domestic legal systems recognize that corporations can be held accountable for harm they cause to others. Part of the core definition of the corporation is that it can both sue and be sued. In all legal systems, corporations are held accountable in some way, be it through criminal or civil procedures or through administrative regulations. The collective enterprise, not just the individuals who compose it, is the legal unit for purposes of both claims and obligations.

\section{Criminal Liability and Equivalent Sanctions}

Legal accountability includes a range of possible procedures and sanctions, including criminal, civil and administrative. In most legal systems, corporate accountability includes criminal liability. ${ }^{100}$

Corporate criminal liability was common in continental Europe in the seventeenth and eighteenth centuries, imposed in great detail, for example, in the French Criminal Code of $1670 .{ }^{101}$ The concept fell into disfavor after the French Revolution, however, when corporate-style associations were disbanded and individualism dominated. ${ }^{102}$ With the rise of industrialization over the course of the nineteenth and early twentieth century came a corresponding interest in holding businesses liable for injuries inflicted by their operations. In England and Canada as well as the U.S., legislatures and courts gradually expanded the notion of corporate criminal accountability. Starting with liability for breaches of statutory duties, by the mid-twentieth century the doctrine had evolved from vicarious liability for the acts of employees to include direct liability for corporate actions. ${ }^{103}$

Most of the civil law systems of continental Europe have returned to corporate criminal liability, led by the Netherlands in the 1920 s and 1930 s. ${ }^{104}$ The Council of Europe gave additional impetus to this movement in 1988, recommending that member states adapt their laws to permit corporate criminal prosecutions. ${ }^{105}$ In response, France amended its laws in 1991, returning to the curiously modern principles of corporate crime that it had followed before the

100. See generally Criminal Liability of Corporations (Hans de Doelder \& Klaus Tiedemann eds., 1996) (XIVth International Congress of Comparative Law); CeliA Wells, CoRpoRations and Criminal Responsibirtry (1993); L.H. Leigh, The Criminal Liability of Corporations and Other Groups: A Comparative View, 80 MicH. L. Rev. 1508 (1982).

101. Guy Stessens, Corporate Criminal Liability: A Comparative Perspective, 43 INT'L \& ComP. L.Q. 493, 494 (1994).

102. Id. at $494-95$.

103. See id. at $495-98$.

104. Id. at 500 .

105. Council of Europe Recommendation No. R(88) 18 . 
revolution. ${ }^{106}$ The Inter-American system as well has recommended that states adapt their laws to permit criminal prosecution of corporations. ${ }^{107}$ The environmental movement has further spurred the recognition of corporate crime, with widespread adoption of statutes imposing criminal sanctions for corporate violations of environmental safeguards. ${ }^{108}$

Exceptions to corporate criminal liability persist. Argentina, for example, maintains the doctrine of societas delinquere non potest, that is, an association cannot be the author of a crime. ${ }^{109}$ Nevertheless, the concept continues to expand in Asia ${ }^{10}$ and Latin America, ${ }^{111}$ and the international trend is toward acceptance of the criminal liability of corporations. ${ }^{112}$ Andrew Clapham offers an interesting indication of the increasing acceptance of the concept of corporate criminal liability-culled, ironically, from the defeat of a proposal to include corporate defendants within the statute of the proposed International Criminal Court. ${ }^{113}$ Clapham details the procedural and definitional problems that led to the withdrawal of the proposal, ${ }^{114}$ but notes that the negotiators demonstrated general support for the theoretical principle that corporations can be bound by criminal law, to the extent that "no delegation challenged the conceptual assumption that legal persons are bound by international criminal law." 115

The question whether legal persons are bound by international criminal law was never posed. The disagreements arose over the complexities involved in interna-

106. WeLls, supra note 100 , at 122.

107. See Inter-American Juridical Committee, Inter-American Model Legislation on Illicit Enrichment and Transnational Bribery, OEA/Ser.Q CJI/doc.70/98 rev. 2, adopted Aug. 22, 1998, ("Although some legal systems do not allow for criminal sanctions the intention is that the legislating State will adapt its law to do so, so as to comply with the Convention.").

108. See, e.g., Donald A. Carr \& William L. Thomas, Devising a Compliance Strategy under the ISO 14000 International Environmental Management Standards, 15 PACE ENVTL. L. REv. 85, 93-94, 94 n.17 (1997) (describing increasing reliance on criminal sanctions for environmental violations); Sevine Ercmann, Enforcement of Environmental Law in United States and European Law: Realities and Expectations, 26 ENVTL. L. 1213, 1218-19 (1996) (detailing use of administrative, civil and criminal sanctions to enforce environmental law in the United States and Europe).

109. Romina Picolotti and Juan M. Picolotti, Human Rights and Corporations: Legal Responsibility of Corporations for Human Rights Abuses in Argentina (Maria-Candela Conforti trans., 2000) (on file with author).

110. See Kevin A. Gaynor \& Thomas R. Bartman, Criminal Enforcement of Environmental Laws, 10 Colo. J. INT'L ENVTL. L. \& Pol'y 39, 92-93 (1999) (describing corporate criminal sanctions for environmental injuries in Asia, including Thailand and Singapore).

111. See id., at $92 \mathrm{n} .330$ (citing corporate criminal penalties in Brazil and other Latin American countries). See also Chijioke Okoli, Criminal Liability of Corporations in Nigeria: A Current Perspective, 38 J. AFr. L. 35 (1994) (1990 Nigerian statute explicitly provides for corporate criminal and civil liability).

112. See, e.g., Theodor Meron, Is International Law Moving Towards Criminalization?, 9 Eur. J. INT'L L. 18, 20 (1998) (noting the international "movement towards this form of criminalization," so that "in the modern business world a corporation itself may be criminally liable for the actions or omissions of agents acting on the corporations behalf ...."); Klaus Tiedemann, Rapport General, in Criminal Liability of CoRporations, supra note 100, at 11, 12-13 (recognizing gradual adoption of corporate criminal liability, although the concept is not yet universally accepted).

113. Andrew Clapham, The Question of Jurisdiction Under International Criminal Law Over Legal Persons: Lessons from the Rome Conference on an International Criminal Court, in LIABILITY of Multinational Corporations, supra note 12, at 139-95.

114. Id. at 157-58.

115. Id. at 191 . 
tional trial of a non-natural person: how to serve the indictment, who would represent the interests of the legal person, how much intention need be proved, how

to ensure that natural persons could not hide behind group responsibility. ${ }^{116}$

In fact, delegates were more concerned about the impact of corporate criminal responsibility on quasi-public corporate entities and non-governmental associations such as the Palestinian Liberation Organization than about the consequences for private corporations. ${ }^{117}$

Within the growing acceptance of corporate criminal liability, there are different approaches to determining when and how a corporation can be held to have committed a crime. According to U.S. federal law, corporations can be held liable when a corporate employee has committed a crime while acting within the scope of his or her authority, with an intent to benefit the corporation. ${ }^{18}$ Each of these requirements has been interpreted broadly. Thus, if a crime includes a required knowledge or intent, a corporation may be held liable based on the collective knowledge of various employees. Virtually all job-related acts are considered within the scope of employment, and a broad range of neutral or even harmful acts are considered to have benefited the corporation. ${ }^{119}$ By contrast, in some legal systems, only the acts of corporate officers or policymakers can be attributed to the corporation. ${ }^{120}$ Yet another approach holds a corporation liable if "its procedures and practices unreasonably fail to prevent criminal violations."121 Once again, however, these differences do not undermine the key building block of corporate accountability: corporations can be held liable for criminal violations committed by their employees, even if legal systems disagree about exactly what behavior by which employees will render the corporation liable.

One indication of the general acceptance of the need to expose corporations to the risk of criminal-like sanctions is that systems that do not directly recognize corporate criminal liability compensate by imposing similar alternatives, thus achieving something virtually identical to penal liability. As Stessens has detailed, such systems employ substitute, or "ersatz" corporate sanctions, "without attaching a "criminal label" "to the penalty. ${ }^{122}$ One such alternative is a system of administrative fines. These differ from criminal fines only in that they are imposed by an administrative agency, not a criminal court-with the conse-

116. Id.

117. Id.

118. John C. Coffee, Corporate Criminal Responsibility, in I Encyclopedia of Crime and Justice 253, 255 (Sanford H. Kadish ed., 1983).

119. Id. at 255-56.

120. Id. at 254-55; Stessens, supra note 101, at 506-10; Wells, supra note 100, at 94.

121. WeLss, supra note 100 , at 95 . Liability for corporate policies is an important response to the fact that the corporation's internal structures may be faulty, whether or not individual employees are also personally responsible for the violation. "[G]enerally the criminal acts of a modern corporation result not from the isolated activity of a single agent, but from the complex interactions of many agents in a bureaucratic setting." Note, Corporate Crime: Regulating Corporate Behavior through Criminal Sanction, Part II: Rationale, 92 HARv. L. Rev. 1231, 1243 (1979).

122. Stessens, supra note 101 , at 498 . See also Leigh, supra note 100, at 1509-10, 1519-20, 1522-23, 1526. Leigh concludes, "Whether the range of sanctions is seen as penal or administrative in nature, the important point is that the sanctions be available." Id. at 1526. 
quence that the corporate "defendant" is deprived of the protections associated with criminal prosecutions. ${ }^{123}$ Another common provision provides that the corporation is civilly liable for a criminal fine assessed against an individual for actions taken on behalf of the corporation. ${ }^{124}$ Through this maneuver, the criminal sanction is actually imposed on the corporation, while still maintaining the position that the corporation cannot be subjected to criminal prosecution.

Differences between legal systems that recognize corporate criminal liability and those that reject it, therefore, are more disagreements about theory than about practice:

[Despite] start[ing] from first principles that are diametrically opposed, they often arrive in practice at a structure of liability that produces broadly similar answers to the problems of corporate crime. The coverage achieved by a system of administrative offenses, or by a system that permits corporations to be fined as a secondary party or assessed damages as a civil consequence of a crime, or by one that contains provisions imposing corporate liability only for certain offenses, for example, may differ little from that achieved under a system of full corporate liability. 125

Under each of these systems, corporations can be held liable for the consequences of their wrongful acts, through penalties that are often identical, whether they be labeled criminal, civil or administrative.

Corporate criminal responsibility in national legal systems is more commonly applied to economic crimes. In practice, criminal prosecutions of corporations for traditional crimes of violence are rare. ${ }^{126}$ This rarity, however, does not result from a theoretical problem but rather appears to be the result of a reluctance to view the corporation as being truly responsible for such crimes rather than the individuals who directly order, direct or commit violent acts. ${ }^{127}$ Where corporate acts of violence fit within the legal requirements for attributing such conduct to the corporation, however, the corporation can be held criminally responsible. Attributing liability for violent human rights abuses to a corporation thus should not be problematic where corporate responsibility is based upon clear corporate policy, such as directing a security force to use violent abuse to repress opponents.

\section{Liability by Any Other Name}

Through the criminal and "ersatz criminal" liability of corporations, in combination with civil and administrative regulation, states assert their power to hold corporations accountable for transgressions of the law. For the purposes of

123. Stessens, supra note 101 , at 502-06. The practice is so common that the European Court of Human Rights has considered the human rights consequences, concluding that certain administrative proceedings are "criminal in nature" and trigger the protections associated with criminal prosecutions, no matter the label assigned to the action by the national legal system. Id. at 504-05.

124. Id. at 501-02. "The technique of holding a corporation civilly liable for criminal fines imposed on natural persons acting on its behalf is widespread in continental legal systems." Id. at 501.

125. Leigh, supra note 100 , at 1509-10.

126. Id. at 1512 .

127. Id. at 1512-13. 
corporate accountability, the exact category to which such accountability is assigned is not material. Corporations can be held accountable through awards of compensatory or punitive damages, through fines payable to the government, or through regulatory orders, up to and including dissolution. While criminal prosecution may have the advantages of greater moral condemnation and punishment in some legal systems, this is not uniformly the case. Regulatory crimes may not carry any moral impact, and in some situations, a finding of civil tort liability will entail both a hefty punishment and moral condemnation. In the U.S., the civil system of punitive damages will often produce more effective sanctions than the cumbersome, rarely used criminal prosecution of corporations.

Assumptions about inherent differences between civil and criminal procedures generally fail when applied to varied legal systems:

[N]ational legal systems draw the line between civil and criminal in different ways. In some systems, criminal prosecutions are always public actions; in others they can be initiated and prosecuted by private parties. Conversely, governments can initiate civil actions that can be as onerous and "punishing" to the civil defendants as criminal prosecutions. ... In some systems, damages for civil claims are always compensatory, in others they serve as a form of punishment as well. Some crimes are punishable only by fines, or orders to compensate the victim; some civil offenses can by "punished" by imprisonment. ... The varieties of civil and criminal claims in domestic legal systems seeking redress for human rights violations span these different categories, with their exact categorization dependent on the definitions used by each system. ${ }^{128}$

Human rights abuses can be addressed in diverse ways. When handled in national legal systems, they must be "translated" into the procedures appropriate to each system. ${ }^{129}$ The key in terms of international law and accountability is that all domestic systems hold corporations accountable, whether through criminal, civil or administrative proceedings.

International law can apply well-developed human rights norms to hold the various corporate entities responsible for their involvement in human rights abuses, and can rely on accepted principles of international jurisdiction to locate the domestic legal systems empowered to impose liability. These remaining topics-international norms and enforcement mechanisms-will be addressed in the following two parts of this article.

V.

\section{Defining the International Human Rights Norms}

GOVERNING CORPORATIONS

Human rights regulation entails both the articulation of norms and the enforcement of those standards. International law has made great strides in articu-

128. Beth Stephens, Translating Filartiga: A Comparative and Intermational Law Analysis of Domestic Remedies For International Human Rights Violations, YALE J. INT'L L. (forthcoming 2002) (manuscript at 51 , on file with author).

129. See generally id. (explaining "translation" of human rights accountability principles into varied national legal procedures). 
lating the human rights norms applicable to corporations, far greater than often acknowledged. Although enforcement is still largely ineffectual, the existence of norms as a benchmark by which to evaluate corporate conduct plays an important role in the movement for corporate accountability.

In this part, I discuss the varied sources of international norms applicable to corporations, looking first at the rapidly growing set of treaties specifically directed at corporations. I then analyze generally binding human rights norms to demonstrate that they apply to corporations as fully as to private individuals. I conclude this part by demonstrating that so-called "voluntary" norms adopted by international and national governments and by corporations actually include many binding rules of law, and suggest that the broader, truly voluntary aspirational standards are likely to develop into binding rules as well.

\section{A. Specific Norms Aimed at Corporations}

An effort in the 1970s and 1980s to draft a comprehensive set of rules governing multinational corporations was unsuccessful. At that time, the underdeveloped and socialist countries sought to impose international rules regulating corporations doing business in their territory, including respect for local priorities and laws and reinvestment of profits in the host countries. ${ }^{130}$ With the triumph of the global economy, such host country efforts have collapsed. In several specific areas, however, treaties define international law obligations that specifically apply to corporations.

Earliest among these was the Apartheid Convention, which established the international crime of apartheid and declared it a crime when committed by "organizations, institutions and individuals." 131 The Apartheid Convention was accompanied by a proposal-never implemented-for an international court to prosecute criminal violations of the treaty ${ }^{132}$ Most recently, the U.N. Convention Against Transnational Organized Crime, opened for signature on December 12,2000 , defined the international crimes of participation in an organized criminal group, money laundering, corruption, and obstruction of justice, all of which applied to corporations as well as natural persons. ${ }^{133}$ In the intervening years,

130. See Development and International Economic Cooperation: Transnational Corporations, U.N. Economic and Social Commission, 2d Sess., Agenda Item 7(d), at 1, U.N. Doc. E/1990/94 (1990).

131. International Convention on the Suppression and Punishment of the Crime of Apartheid, art. I(2), U.N. Doc. A/2645 (1953) (entered into force July 18, 1976).

132. Draft Convention on the Establishment of an International Penal Tribunal for the Suppression and Punishment of the Crime of Apartheid and Other International Crimes, reproduced in M.C. Bassiouni, The Statute of the International Criminal Court: A Documentary History (1998). According to the proposal, persons, legal entities, groups and organizations would all have been subject to the jurisdiction of the court. Id. at arts. $5,6,21(4)$.

133. United Nations Convention Against Transnational Organized Crime (advance copy of the authentic text of the treaty), arts. 5, 6, 8, 23, available at http://www.uncjin.org/Documents/Conven tions/dcatoc/final_documents_2/convention_eng.pdf (last visited Apr. 18, 2001). As of December 15,2000 , the treaty had been signed by 124 states, including the United States. See U.N. Office for Drug Control and Crime Prevention, Annex: United Nations Convention Against Transnational Organized Crime and the Protocols Thereto, at http://www.undcp.org/crime_cicp_signatures.html (last visited Apr. 18, 2001). 
several treaties have established international corporate crimes connected to bribery and corruption. ${ }^{134}$ The European Convention on Corruption, for example, calls for national prosecutions of "legal persons" for the crimes of bribery, trading in influence and money laundering. ${ }^{135}$

Another set of international treaties addresses corporate environmental violations. The Convention on Transboundary Movements of Hazardous Wastes criminalizes unauthorized movement of hazardous wastes committed by any "person"-including corporations as well as individuals. ${ }^{136}$ In addition, a number of international agreements create civil liability for environmental damage caused by corporations. ${ }^{137}$ The Convention on Civil Liability for Oil Pollution Damage, for example, imposes civil liability on ship owners for damage caused by oil pollution. ${ }^{138}$

Each of these treaties calls upon state parties to enact legislation making the prohibited conduct a crime under national law or imposing civil liability upon corporate violators. That is, rather than establishing an international enforcement mechanism, they instead require states to enact domestic measures of enforcement. The lack of international enforcement and the need for national action, however, should not be mistaken for the absence of an international norm. The standard of conduct, the definition of the crime or the civil wrong, is established by the international agreement; as is the case with most international norms, enforcement is left to the national legal system. As Professor Clapham points out, these treaties make clear that the international legal system is capable of defining international legal standards applicable to corporations. "[T]he international legal order has already adapted to define corporate crimes in international law and to oblige States to criminalize this behaviour."139

These detailed treaties demonstrate that states have the authority to develop rules specifically applicable to corporations. In addition, many human rights

134. See, e.g., Council of Europe Criminal Law Convention on Corruption, opened for signature Jan. 27, 1999, art. 18, Europ. T.S. No. 173, at 6, 38 I.L.M. S05, 509 (active bribery, trading in influence and money laundering); Inter-American Convention Against Corruption, Mar. 29, 1996, art. 8, 35 I.L.M. 724, 730 (prohibiting offering article of monetary value to a government official of another state); OECD Convention on Combating Bribery of Foreign Public Officials in International Business Transactions, Dec. 17, 1997, art. 1, available at http://www.oecd.org/daf/nocorr-uption/ 20novle.htm (bribery of foreign public officials).

135. Council of Europe Criminal Law Convention on Corruption, supra note 134, at art. 18(1).

136. Basel Convention on the Control of Transboundary Movements of Hazardous Wastes and Their Disposal, Mar. 22, 1989, arts. 2, 4, 28 I.L.M. 657, 662. See discussion in Clapham, supra note 113 , at $173-74$.

137. See, e.g., International Convention on Civil Liability for Oil Pollution Damage, Nov. 29, 1969, art. 3, 973 U.N.T.S. 4, 5 (entered into force June 19, 1975) (92 states ratified; United States signed) ("[T]he owner of a ship ... shall be liable for any pollution damage caused by oil ..."), as amended by the Protocol of 1992, art. 4; Convention on Civil Liability for Damage Resulting from Activities Dangerous to the Environment, June 21, 1993, arts. 6, 7, 32 I.L.M. 1228, 1233-34 (operator of polluting facility or waste dump liable for damage); Bamako Convention on the Ban of Import into Africa and the Control of Transboundary Movement and Management of Hazardous Wastes within Africa, opened for signature Jan. 30, 1990, art. 4(3)(b), 30 I.L.M. 773 (signed by 22 nations) (imposing strict liability on generators of hazardous wastes within states).

138. International Convention on Civil Liability for Oil Pollution Damage, supra note 137, at art. 3.

139. Clapham, supra note 113 , at 178. 
norms of general application bind private individuals and corporations, as well as state officials and states themselves. In the next section, I analyze the history of international regulation of corporate human rights abuses to demonstrate that corporations are bound by the core human rights norms.

\section{B. Universal Human Rights Norms and Corporations}

The international community has determined over the past fifty years that certain actions are prohibited and constitute violations of international law whether or not a state is a party to treaties outlawing the acts. These violations are prohibited by customary international law, binding on all regardless of state consent. The most egregious example is genocide, the intentional destruction, in whole or in part, of a national, ethnic, racial or religious group. ${ }^{140}$ Others include summary execution, torture, and slavery and the slave trade. ${ }^{141}$ Most of the international agreements that codify these and other human rights obligations are addressed to states, calling on states to enforce the listed obligations. But the norms embedded in the agreements bind the behavior of private individuals and corporations alike. International law has never been limited to regulating state behavior. Over the past fifty years, the international community has moved decisively to expand not only the rights of non-state actors but their responsibilities as well.

\section{Individuals}

The application of international law to individuals has been much debated, with "traditionalists" arguing that only states can be bound by international law's strictures. ${ }^{142}$ This view, however, is both historically inaccurate and rejected by modern international law.

Historically, international law has long barred piracy, a violation that by definition is committed by stateless private actors. ${ }^{143}$ The prohibition of the slave trade also applies to all actors, private as well as public. ${ }^{144}$ Almost fifty years ago, the Nuremberg Tribunal reaffirmed the principle of individual responsibility, now a bedrock of modern international human rights law, in stirring language, stating, "[T]hat international law imposes duties and liabilities upon

140. Convention on the Prevention and Punishment of the Crime of Genocide, Dec. 9, 1948, art. 2, 102 Stat. 3045, 78 U.N.T.S. 277 [hereinafter Genocide Convention].

141. The full list adopted by the Restatement (ThIRD) OF THE Foreign Relations Law of the United States [hereinafter Restatement of the Foreign Relations Law] \& 702 (1987), includes genocide; slavery or the slave trade; murder or causing disappearance; torture or other cruel, inhuman, or degrading treatment; prolonged arbitrary detention; systematic racial discrimination; and "a consistent pattern of gross violations of internationally recognized human rights."

142. Clapham describes-and rebuts-this "traditional" view. Andrew Clapham, Human Rights in the Private Sphere 89-91, 93-133 (1993).

143. Piracy consists of "[a]ny illegal acts of violence, detention or any act of depredation, committed for private ends by the crew or the passengers of a private ship or a private aircraft ...." Convention on the High Seas, Apr. 29, 1958, arts. 15, 16, 13 U.S.T. 2312, 2317, 450 U.N.T.S. 82, 90; see also Convention on the Law of the Sea, Dec. 10, 1982, arts. 101, 102, 1833 U.N.T.S. $3,436$.

144. See Slavery Convention, Sept. 25, 1926, 60 L.N.T.S. 253; Supplementary Convention on the Abolition of Slavery, the Slave Trade, and Institutions and Practices Similar to Slavery, Sept. 7, 1956, 18 U.S.T. 3201,266 U.N.T.S. 3. 
individuals as well as upon States has long been recognized. ... Crimes against international law are committed by men, not by abstract entities, and only by punishing individuals who commit such crimes can the provisions of international law be enforced."145 The Nuremberg judgment thus took general international rules of behavior and applied them to individuals. ${ }^{146}$

Today, however, the application of international law to individuals is widely recognized. For example, The Genocide Convention, a modern outgrowth of the principles stated at Nuremberg, applies by definition to private actors as well as public officials. The Genocide Convention states that "persons committing genocide shall be punished, whether they are constitutionally responsible rulers, public officials or private individuals."147 The preamble to the Universal Declaration of Human Rights states that "every individual and every organ of society" should promote respect for basic human rights. ${ }^{148}$ Both the International Covenant on Civil and Political Rights and the International Covenant on Economic, Social and Cultural Rights recognize private obligations in their preambles, in the following terms: "Realizing that the individual, having duties to other individuals and to the Community of which he belongs, is under a responsibility to strive for the promotion and observance of the rights recognized in the present Covenant." ${ }^{149}$ Moreover, all of the international agreements regulating corporations that were discussed in the prior section specifically govern the activities of private actors.

Clapham makes an additional argument for recognizing private rights and duties in the international human rights documents, based upon understanding the evolving context in which the documents were drafted and are currently interpreted. He argues for a broad, contextual interpretation of international agreements, stating that "it is neither a literal nor a teleological interpretation but a contextual/evolutive/dynamic one that is most appropriate" to an understanding of international law. ${ }^{150}$ As stated by the International Court of Justice, "[A]n international instrument has to be interpreted and applied within the framework of the entire legal system prevailing at the time of the interpretation." ${ }^{151}$ The ICJ concluded that the application of a fifty-year-old international agreement "must take into consideration the changes which have occurred in the supervening half century, and its interpretation can not remain unaffected by the

145. Judgment of Oct. 1, 1946, Transcript of Proceedings.

146. The Nuremberg judgments applied these general norms to corporations as well as to individuals, as discussed later in this part.

147. Genocide Convention, supra note 140, at art. 4.

148. Universal Declaration of Human Rights, Preamble, Dec. 10, 1948, U.N. Doc. A/810 [hereinafter Universal Declaration].

149. International Covenant on Civil and Political Rights, Dec. 19, 1966, Preamble, para. 5, 999 U.N.T.S. 171, 173 (entered into force Jan. 3, 1976); International Covenant on Economic, Social and Cultural Rights, Dec. 19, 1966, Preamble, para. 5, 993 U.N.T.S. 3, 5 (entered into force Jan. 3 1976).

150. Clapham, Human Rights, supra note 142, at 98-99.

151. Id. at 99, citing Advisory opinion of the ICJ on the Legal Consequences for States of the Continued Presence of South Africa in Namibia (South West Africa) [1971] ICJ Rep. 31, II 53. 
subsequent development of law," including customary international law as well as treaty law. ${ }^{152}$

The context in which international human rights norms must be interpreted and applied today is one in which such norms are routinely applied to private actors. Human rights law in the past several decades has moved decisively to prohibit violations by private actors in fields as diverse as discrimination, children's rights, crimes against peace and security, and privacy. ${ }^{153}$ Significant provisions of international humanitarian law apply to non-state actors. ${ }^{154}$ International and regional human rights bodies frequently call upon states to prevent human rights abuses committed by private actors. ${ }^{155}$ It is clear that individuals today have both rights and responsibilities under international law. Although expressed in neutral language, many human rights provisions must be understood today as applying to individuals as well as to states.

\section{Complicity}

Certain international human rights prohibitions are triggered only with some level of state involvement or complicity. The Convention Against Torture, for example, prohibits torture "inflicted by or at the instigation of or with the consent or acquiescence of a public official or other person acting in an official capacity." 156 However, this and other international law prohibitions apply to those who are complicit in violations or participate in other ways. ${ }^{157}$ The Genocide Convention, for example, prohibits both complicity and conspiracy to commit genocide, as well as prohibiting genocide itself. ${ }^{158}$ The Torture Convention requires states to criminalize any act "that constitutes complicity or participation in torture." 159 Similarly, the Supplementary Slavery Convention establishes liability for "being an accessory thereto" of the enslavement of an-

152. Id.

153. Id. at $99-102$.

154. Id. at 112-18. For example, common Article 3 of the four Geneva Conventions sets minimal rules applicable to all parties engaged in armed conflict, including private parties as well as states. Geneva Convention Relative to the Protection of Civilian Persons in Time of War, Aug. 12, 1949, art. 3, 6 U.S.T. 3516, 3518-3521, 75 U.N.T.S. 287, 288-289; Geneva Convention Relative to the Treatment of Prisoners of War, Aug. 12, 1949, art. 3, 6 U.S.T. 3316, 3318-3321, 75 U.N.T.S. 135, 136; Geneva Convention for the Amelioration of the Condition of the Wounded, Sick and Shipwrecked Members of Armed Forces at Sea, Aug. 12, 1949, art. 3, 6 U.S.T. 3217, 3220-3223, 75 U.N.T.S. 85, 86; Geneva Convention for the Amelioration of the Condition of the Wounded and Sick in Armed Forces in the Field, Aug. 12, 1949, art. 3, 6 U.S.T. 3114, 75 U.N.T.S. 31, 32. The Second Protocol to the Conventions similarly applies to private parties engaged in internal armed conflicts. Protocol Additional to the Geneva Conventions of 12 August 1949, and Relating to the Protection of Victims of Non-International Armed Conflicts, June 8, 1977, art. 13, 1125 U.N.T.S. 609.

155. Clapham, Human Rights, supra note 142, at 107-12, 118-24.

156. Convention Against Torture and Other Cruel, Inhuman or Degrading Treatment or Punishment, Dec. 10, 1984, art. 1(1), 1465 U.N.T.S. 113, 113 (entered into force June 26, 1987) [hereinafter Torture Convention].

157. See sources cited infra, notes 158-60.

158. Genocide Convention, supra note 140, art. 3 .

159. Torture Convention, supra note 156, art. 4(1). 
other person, or "being a party to a conspiracy to accomplish any such acts." 160 Thus, private actors violate these international norms when they participate with official actors in acts constituting prohibited violations.

From the time of the Nuremberg Tribunals through recent decisions of the International Criminal Tribunals for the Former Yugoslavia and for Rwanda, international law has recognized that those who conspire to commit an international crime or aid and abet its commission are criminally liable along with the principals. Several World War II cases found defendants guilty of war crimes and crimes against humanity as accomplices to the crimes. In The Zyklon B Case, ${ }^{161}$ for example, several German industrialists were convicted of supplying poison gas to Nazi concentration camps based on proof that they knew the purpose for which the gas was to be used. ${ }^{162}$

The modern international criminal tribunals have applied the holdings of the World War II cases to develop an international law definition of aiding and abetting. ${ }^{163}$ In a case arising in Rwanda, the tribunal held that the required actus reus was "practical assistance, encouragement, or moral support which has a substantial effect on the perpetration of the crime." 164 The required mens rea was that the accomplice "have knowledge that his actions [would] assist the perpetrator in the commission of the crime;" it required neither intent to commit the crime nor even knowledge of the exact crime to be committed. ${ }^{165}$ Reviewing the common understandings as to accomplice liability in domestic legal systems, the Rwanda tribunal concluded both that all criminal systems provide that an accomplice can be tried in absence of the principal perpetrator and that the accomplice need not intend the principal offense: "As a result, anyone who knowing of another's criminal purpose, voluntarily aids him or her in it, can be convicted of complicity even though he regretted the outcome of the offense."166 The statute of the International Criminal Court similarly holds liable

160. Supplementary Convention on the Abolition of Slavery, the Slave Trade, Institutions and Practices Similar to Slavery, Sept. 7, 1956, art. 6266 U.N.T.S. 3, 43.

161. The Zyklon B Case (Trial of Bruno Tesch and Two Others), 1 Law Reports of Trials of War CRIminals 93 (Brit. Mil. Ct. 1946).

162. Id. at 100 . Similarly, Friederich Flick was convicted for knowingly contributing financial support to the Nazis. U.S. v. Flick, 6 Trials of War Criminals Before the Nuremberg Military Tribunals Under Control Council Law No. 10, at 1, 1216-23 (1949). In U.S. v. Krauch, pharmaceutical industrialists were convicted because they knowingly supplied experimental vaccines to the Nazis, knowing they would be used in illegal medical experiments on concentration camp inmates. 8 Trials of WAR CRIMINALS, 1081, 1169-72 (1952).

163. See generally Brief of Amici Curiae International Human Rights Organizations and International Law Scholars in Support of Plaintiffs-Appellants, Doe v. Unocal Corp., 248 F.3d 915 (9th Cir. 2001), at 7-19 (international law recognizes concept of complicity and does not require actual participation), available at www.aclu.org/library/iclr/2000/iclr2000_6.pdf.; Andrew Clapham \& Scott Jerbi, Categories of Corporate Complicity in Human Rights Abuses (Mar. 2001) (on file with author).

164. Prosecutor v. Furundzija, IT-95-17/1-PT (Dec. 10, 1998), II 249. Moral support is sufficient where such support has "a significant legitimizing or encouraging effect on the principals." Id. II 232.

165. Id. I 246.

166. Prosecutor v. Akayesu, Case No. ICTR-96-4-T (Int'l Crim. Trib. for Rwanda, Trial Chamber I, Sept. 2, 1998), TII 531, 539, at http://www.ictr.org/ENGLISH/cases/Akayesu/judgement/akay 001.htm. Quoting an English case, the Rwanda tribunal stated: 
a person who, "[f]or the purpose of facilitating the commission" of a crime, "aids, abets or otherwise assists in its commission. . . ."167

In the non-criminal context of state responsibility for violations of international law, international tribunals have also recognized the concept of complicity. Thus, both the European Court of Human Rights and the United Nations Human Rights Committee have held that a state violates international law where it extradites a person to a country where the fugitive is likely to be subjected to human rights violations. ${ }^{168}$

International human rights organizations also insist upon accountability that reaches beyond direct actions. Applying this principle to corporations, Human Rights Watch holds companies responsible for "human rights abuses that are being committed on their behalf and in their interest." 169 This responsibility goes beyond the "most egregious examples," such as when a company requests, pays for or supervises security operations that involve human rights violations. ${ }^{170}$ Where company operations are "deeply intertwined" with repressive actions, the corporation has an obligation to take affirmative actions to ensure that abuses are not committed on its behalf. ${ }^{171}$

Non-state actors thus violate international norms when they are complicit in such abuses, as well as when they directly commit abuses. Moreover, private actors violate the norms requiring state action when they participate in acts taken in complicity with state actors. These principles apply to corporations as well as individuals, as discussed in the next section.

\section{Corporations as well as Private Individuals}

General human rights norms apply to individuals as well as to states. Although international enforcement mechanisms may be weak, with enforcement often left to domestic legal systems, the international rules of law prohibiting, for example, genocide, slavery and torture bar such conduct by individuals as well as by governments. Where some public action is required under interna-

[A]n indifference to the result of the crime does not of itself negate abetting. If one man deliberately sells to another a gun to be used for murdering a third, he may be indifferent about whether the third lives or dies and interested only in the cash profit to be made out of the sale, but he can still be an aider and abettor.

Akayesu, II 539 (quoting National Coal Board v. Gamble, 1 Q.B. 11 (1959)).

167. Statute of the International Criminal Court, July 17, 1998, U.N. Doc. A/CONF.183/9 (1998), art. 25, §3(c).

168. See generally Soering v. United Kingdom, 11 E.H.R.R. 439 (1989) (European Court of Human Rights held that the United Kingdom would be responsible for violations where there was substantial reason to believe Soering would be subjected to torture or other inhuman or degrading treatment if extradited); Ng v. Canada, U.N. Doc. CCPR/C/49/D/469/1991 (1994) (U.N. Human Rights Committee found violation of international law where Canada extradited petitioner knowing that human rights violations might occur).

169. Human Rights Watch, The Price of Oil: Corporate Responsibility and Human Rights Violations in Nigeria's Oil Producing Communities, Summary, at http://www.hrw.org/hrw/press/1999/ feb/nigsumm.htm (last visited June 5, 2001).

170. Id.

171. Id. 
tional law, the norm applies to private individuals who act in complicity with state actors.

The same concepts underlie the application of international human rights norms to corporations. ${ }^{172}$ Indeed, given the widespread recognition of corporate accountability within domestic legal systems, such an application is not surprising. International tribunals have applied human rights and humanitarian norms to corporations from the time of the Nuremberg Tribunals. That legacy, combined with the international consensus on corporate accountability, underlies the application of human rights provisions to corporate as well as individual persons.

The Nuremberg Tribunal made clear that norms applicable to "persons" applied to legal persons as well as individuals. ${ }^{173}$ Thus, organizations were declared to be criminal where their purpose was to commit or facilitate crimes detailed in the Charter:

A criminal organization is analogous to a criminal conspiracy in that the essence of both is cooperation for criminal purposes. There must be a group bound together and organized for a common purpose. The group must be formed or used in connection with the commission of crimes denounced by the Charter. ${ }^{174}$

The Nuremberg Charter authorized the criminal prosecution of only individuals, thus the groups labeled "criminal organizations" were not actually subject to criminal charges. ${ }^{175}$ But, in applying the Charter in the area under its control, the United States Military Tribunal found that the I.G. Farben Corporation had violated international law:

[W]e find that the proof establishes beyond a reasonable doubt that offences against property as defined in Control Council Law No. 10 were committed by Farben, and that these offences were connected with, and an inextricable part of the German policy for occupied territories. ${ }^{176}$

Farben in these passages is held to have violated international law prohibitions against pillage and plunder:

172. See Kamminga \& Zia-Zarifi, supra note 12, at 8-9 (noting the "growing consensus that MNCs are bound by those few rules applicable to all international actors," including, inter alia, the prohibitions of slavery and forced labor, genocide, torture, extrajudicial murder, piracy, crimes against humanity and apartheid).

173. See Clapham, supra note 113, at 160-71 (discussing Nuremberg application of international law to corporations). Various international and national documents use the terms "juridical person," "legal person," "juristic persons" and "corporations" to refer to the organizations recognized as having legal status. Id. at 152,152 n.24.

174. Nuremberg Judgment, The Accused Organizations, Oct, 1, 1946, reprinted in 41 Ам. J. INT'L L. 172 (1947).

175. The jurisdiction of the International Military Tribunal included only prosecution of natural persons. Charter of the International Military Tribunal, annexed to Agreement for the Prosecution and Punishment of the Major War Criminals of the European Axis, Aug. 8, 1945, art. 659 Stat. 1544,82 U.N.T.S. 279 (granting the Tribunal authority to evaluate the "individual responsibility" of "persons" who acted as "individuals or as members of organizations"). Organizations, however, could be held to be "criminal," subjecting certain members to prosecution for the crime of membership in a criminal organization. Id., arts. 9, 10.

176. Case No. 57, The I.G. Farben Trial, U.S. Military Tribunal, Nuremberg, 14 Aug. 1947July 29, 1948, 10 Law Reports of Trials of War Criminals 1; 8 Trials of War Criminals Before the Nuremberg Milttary Tribunals 1108, 1140, INT'L L. Rep. 676 (1948) (emphasis added) [hereinafter 8 Trials of WAR Criminals]. 
The result was the enrichment of Farben and the building of its greater chemical empire through the medium of occupancy at the expense of the former owners. Such action on the part of Farben constituted a violation of the rights of private property, protected by the Laws and Customs of War .... 177

Thus, these general humanitarian law provisions governing the laws and customs of war applied to legal persons as well as individuals.

Despite some reluctance to apply international criminal law to corporations in the mid-twentieth century, the concept of international corporate crimes is now common. ${ }^{178}$ As discussed above, several international treaties have expressly included corporate crimes, including the Apartheid Convention, and treaties governing corruption and bribery, hazardous wastes, and other environmental violations.

The absence of criminal prosecution as an enforcement mechanism does not detract from the conclusion that the norms bind corporate actors. International law and domestic legal systems may choose to enforce international norms through civil or administrative proceedings, as well as criminal prosecutions. ${ }^{179}$ Moreover, discussion about criminal prosecution should not mask the more fundamental recognition that such conduct is prohibited-a violation of international law-even in the absence of specific enforcement mechanisms.

The preamble to the Universal Declaration of Human Rights contains a pointed application that goes beyond both states and individuals:

The General Assembly proclaims this Universal Declaration of Human Rights as a common standard of achievement for all peoples and all nations, to the end that every individual and every organ of society, keeping this Declaration constantly in mind, shall strive by teaching and education to promote respect for these rights and freedoms and by progressive measures, national and international, to secure their universal and effective recognition and observance, both among the peoples of Member States themselves and among the peoples of territories under their jurisdiction. ${ }^{180}$

As Professor Louis Henkin has emphasized, "Every individual includes juridical persons. Every individual and every organ of society excludes no one, no company, no market, no cyberspace. The Universal Declaration applies to them all." 181 Corporations are independent legal entities, subject to international and domestic regulation and capable of being held legally accountable for their actions. When an international agreement applies broadly to all actors, it applies

177. 8 Trials of WAR Criminals, supra note 176, at 1132, 1140 (emphasis added).

178. In both 1951 and 1953, the International Law Commission chose to exclude legal persons because some legal systems did not recognize penal responsibility on the part of legal entities. In the words of the 1953 report, the Commission decided to omit "so novel a principle as corporate criminal responsibility." U.N. Doc. A/2645 (1953). See Clapham, supra note 113, at 171-72, for a discussion of this history.

179. Similarly, the fact that the Statute of the International Criminal Court does not authorize international criminal prosecution of corporations implies nothing about the applicability of the norms covered by the court to legal persons: "[L]ack of ICC jurisdiction over legal persons for war crimes should not mislead us into thinking that the laws of war and international human rights law do not apply to companies." Clapham, supra note 113 , at 178 .

180. Universal Declaration, supra note 148, preamble (emphasis added).

181. Louis Henkin, The Universal Declaration at 50 and the Challenge of Global Markets, 25 BrooK. J. INT'L L. 17, 25 (1999) (emphasis in original). 
to corporations as well. In the realm of core human rights norms, multinational corporations "are bound by those few rules applicable to all international actors." 182

The international committees that interpret human rights agreements increasingly apply them in this manner to corporations. Thus, the United Nations Committee on Economic, Social and Cultural Rights has said that:

[A]ll members of society-individuals, families, local communities, non-governmental organizations, civil society organizations, as well as the private business sector, have responsibilities in the realization of the right to adequate food. . . . The private business sector-national and transnational-should pursue its activities within the framework of a code of conduct conducive to respect of the right to adequate food. ${ }^{183}$

The Committee has used similar language in reference to the right to health. ${ }^{184}$ In addition, the Human Rights Committee has stated that private entities are governed by the protection of the right to privacy. ${ }^{185}$ Non-binding resolutions at numerous international conferences have applied human rights obligations in the area of discrimination, the environment, human rights and development to private corporations. ${ }^{186}$

Although international law norms are often viewed as addressed only to states, many in fact apply to corporate persons as well as to private individuals and state officials and to states themselves.

\section{C. "Voluntary" Codes/Binding Rules}

Before discussing enforcement mechanisms, this section will address a curious phenomenon of the past decade: "voluntary" codes of corporate conduct. Such codes have their roots in a series of codes of conduct drafted by the United Nations and other international organizations in the 1970 s, at a time when developing countries were most vocal in their concerns about the impact of multinational corporations on their economies. ${ }^{187}$ The first of these, the draft U.N.

182. Kamminga \& Zia-Zarifi, supra note 12 , at 8 .

183. U.N. Committee on Economic Social and Cultural Rights, General Comment 12, The Right to Adequate Food (Art. 11), May 12, 1999, para. 20.

184. U.N. Committee on Economic Social and Cultural Rights, General Comment 14, The Right to the Highest Attainable Standard of Health (Art. 12), July 4, 2000, para. 42.

185. U.N. Human Rights Committee, General Comment 16, The Right to Respect of Privacy, Family, Home and Correspondence, and Protection of Honor and Reputation (Art. 17), April 8, 1988.

186. International Council on Human Rights Policy, Business Rights and Wrongs: Human Rights and the Developing International Legal Obligations of Companies 39 (2001) (draft report), at http://www.ichrp.org.

187. "Between 1970 and 1981 , virtually all major international governmental organizations interested in international trade and investment developed detailed proposals for MNE codes of conduct." Baker, supra note 39, at 409 (citing Hans V. Baade, Codes of Conduct for Multinational Enterprises, in 1 Legal Problems of Codes of Conduct for Multinational Enterprises 407, 412 (Norbert Horn ed., 1980)).

The concept of voluntary codes of conduct rests upon a historical tradition of corporate selfregulation, tracing back to medieval Europe, through to the beginnings of the U.S. industrial economy. See antony Black, Guilds and Civil Society in European Political Thought From the Twelfth Century to the Present 4, 6 (1984); Harvey L. Pitt \& Karl A. Groskaufmanis, 
Code of Conduct for Transnational Corporations, aimed primarily at regulating corporate meddling in the internal affairs of developing countries, was never adopted. ${ }^{188}$ The draft code included general human rights language, stating that "[t]ransnational corporations shall respect human rights and fundamental freedoms in the countries in which they operate" and prohibiting discrimination. ${ }^{189}$

Perhaps the most well-known of the private codes was the Sullivan Principles, a code of conduct for businesses operating in apartheid South Africa that prohibited discrimination. ${ }^{190}$ Corporations were asked to pledge compliance and to report on their efforts. The author of the principles, Leon Sullivan, later criticized the code as ineffective, largely because of the lack of enforcement mechanisms. ${ }^{191}$ Similar efforts in the 1980s addressed corporate activities in Northern Ireland, the Soviet Union and China. ${ }^{192}$

A host of such codes of conduct have been drafted by governmental and private organizations as well as by corporations over the past decade. Multilateral international efforts include the Compact for the New Century sponsored by U.N. Secretary General Kofi Annan ${ }^{193}$ as well as a draft circulated by the subcommission of the U.N. Human Rights Commission. ${ }^{194}$ The European Parliament has proposed a similar code, as well as calling for adoption of a binding code of conduct. ${ }^{195}$ On a national level, the U.S. government has worked with business representatives on codes to govern both the apparel industry and mining and petroleum industries. ${ }^{196}$ Private efforts include codes developed by corporations themselves and those drafted by a wide range of independent nongovernmental organizations.

Minimizing Corporate Civil and Criminal Liability: A Second Look at Corporate Codes of Conduct, 78 GEo. L. J. 1559, 1561, 1576-78 (1990); Baker, supra note 39, at 407.

188. See Development and International Economic Cooperation: Transnational Corporations, U.N. Economic and Social Commission, 2d Sess., Agenda Item 7(d), at 1, U.N. Doc. E/1990/94 (1990).

189. Id.

190. Sullivan Principles for U.S. Corporations Operating in South Africa, 24 I.L.M. 1496 (1985) (citing "The (Sullivan) Statement of Principles" (Fourth Amplification), Nov. 8, 1984).

191. See Leon Sullivan, The Sullivan Principles and Change in South Africa, in BusINESS IN THE Contemporary World 175 (Herbert L. Sawyer ed., 1988); Karen Paul, The Inadequacy of Sullivan Reporting, 57 Bus. \& Soc. R. 61 (1986).

192. See discussion of these codes in Lance Compa \& Tashia Hinchliffe-Darricarrere, Enforcing International Labor Rights Through Corporate Codes of Conduct, 33 Colum. J. Transnat'L L. $663,671-72$ (1995).

193. U.N. Secretary-General Kofi A. Annan, A Compact for the New Century, at http://www.un globalcompact.org/un/gc/unweb.nsf/content/thenine.htm (last visited Apr. 14, 2001) [hereinafter U.N. Compact].

194. See generally David Weissbrodt, The Beginning of a Sessional Working Group on Transnational Corporations Within the UN Sub-Commission on Prevention of Discrimination and Protection of Minorities, in Liabiltty of Multinational Corporations, supra note 12, at 119-38.

195. Resolution on EU Standards for European Enterprises Operating in Developing Countries: Towards a European Code of Conduct, European Parliament, Resolution A4-0508/98.

196. Bureau of National Affairs, Inc., Voluntary "Model Business Principles" Issued by the Clinton Administration, May 26, 1995, Daily Rep. For Executives, May 31, 1995, http://www.itcilo. it/english/actrav/telearn/global/ilo/guide/usmodel.htm (last visited Nov. 3, 2001) [hereinafter U.S. Dep't of Commerce]. 
Perhaps the most striking fact about these "voluntary" codes is the extent to which they incorporate human rights norms that are, in fact, obligatory duties, not voluntary undertakings. The U.N. Compact, for example, calls on world business to "respect the protection of international human rights within their sphere of influence" and "make sure their own corporations are not complicit in human right abuses." 197 The Compact proceeds to ask business leaders to respect the four most fundamental labor rights principles that were adopted by unanimous consensus by the 170 members of the International Labor Organization: freedom of association and the effective recognition of the right to collective bargaining; the elimination of all forms of forced and compulsory labor; the effective abolition of child labor; and the elimination of discrimination in respect of employment and occupation. ${ }^{198}$

Similarly, the self-proclaimed voluntary Guidelines for Multinational Enterprises drafted by the Organization for Economic Cooperation and Development call on corporations to "[r]espect the human rights of those affected by their activities" and to "contribute to the effective elimination of child labor" and "forced or compulsory labor in their operations." 199 The ILO itself has adopted a non-binding declaration of principles that urges "All parties"- governments, employers and trade unions-to "respect the Universal Declaration of Human Rights" as well as the two International Covenants. ${ }^{200}$ The Model Business Principles issued by the Clinton Administration follow this same pattern, terming their provisions voluntary, although they include a pledge to avoid forced labor and to comply with U.S. and local law. ${ }^{201}$

Despite the voluntary language in these codes, it is difficult to imagine a corporation arguing that it is not obligated to respect human rights and to refrain from using forced labor. The prohibition against forced labor has been a core, obligatory feature of international law for almost fifty years, since the adoption of the Supplementary Slavery Convention. ${ }^{202}$ Use of forced labor violates international law-and there is nothing voluntary about a corporation's agreement to refrain from doing so. Similarly, paying a security force to commit torture violates international law; corporations do not "voluntarily" choose to abide by this international norm. This is not to deny that there is some importance to a pledge to abide by the law. Obviously, obligations are not actually honored in practice, and anything that contributes to greater compliance is useful. But, the fact that such obligations are included in "voluntary" codes should not obscure the obligatory foundation of many of the norms included in the codes.

197. U.N. Compact, supra note 193, §§ 1(a), (b).

198. Id. at $\S(2)$.

199. OECD Guidelines for Multinational Enterprises, $\mathrm{H}(2), \mathrm{IV}(1)(\mathrm{c})$, available at http://www 1 . oecd.org/daf/investmentguidelines/mnetext.htm (last visited Nov. 3, 2001). The OECD guidelines were first drafted in 1976; this reference to respect for human rights was inserted in the most recent revision, in June 2000.

200. Tripartite Declaration of Principles Concerning Multinational Enterprises and Social Policy, International Labor Organization, art. 8, 17 I.L.M. 422, 425-28 (1978).

201. U.S. Dep't of Commerce, supra note 196.

202. Supplementary Convention on the Abolition of Slavery, the Slave Trade, and Institutions and Practices Similar to Slavery, Sept. 7, 1956, 226 U.N.T.S. 3. 
The sad reality is that the weak language of most of these codes reflects the economic and political power of multinational corporations. The United Nations, for example, has acknowledged that the Global Compact is voluntary because corporations would not accept a binding commitment. ${ }^{203}$ Critics have charged that the U.N. is "making peace with power," while abandoning the drive to strengthen legally binding norms. ${ }^{204}$

It is interesting to note, however, that the United Nations at the time of its foundation made a similar "peace with power" with surprising results, drafting an aspirational human rights code that has since evolved into a powerful human rights platform. The Universal Declaration of Human Rights was drafted as a non-binding document because the states belonging to the United Nations refused to agree to binding norms. As described by Eleanor Roosevelt, a key leader in the drafting and passage of the Declaration:

In giving our approval to the declaration today, it is of primary importance that we keep clearly in mind the basic character of the document. It is not a treaty; it is not an international agreement. It is not and does not purport to be a statement of law or of legal obligation. It is a declaration of basic principles of human rights and freedoms, to be stamped with the approval of the General Assembly by formal vote of its members, and to serve as a common standard of achievement for all peoples of all nations. ${ }^{205}$

The United Nations described the Universal Declaration as originally "a manifesto with primarily moral authority." 206 Nevertheless, half a century later, the document is now considered to be binding, in important part, if not in total. ${ }^{207}$

Today's "voluntary" codes of business conduct are already, in part, statements of binding international law. To the extent that they extend beyond currently existing law, they may follow the path of the Universal Declaration, acquiring binding status through their incorporation into customary international law or international treaties. ${ }^{208}$

203. Irwin Arieff, UN: One Year Later Global Compact Has Little To Show, ReuTERs, July 27, 2001 (U.N. Assistant Secretary-General Michael Doyle "acknowledged the program's [voluntary] form was in part dictated by a recognition that the corporate world was unwilling to accept binding global standards on corporate governance").

204. George Monbiot, The United Nations is Trying to Regain its Credibility by Fawning to Big Business, THE Guardian, Aug. 31, 2000 (The U.N. is "helping western companies to penetrate new markets while avoiding the regulations which would be the only effective means of holding them to account. By making peace with power, the U.N. is declaring war upon the powerless.").

205. Quoted in 5 Marjorie M. Whiteman, Digest of International Law 243 (Washington, D.C.: Dept. of State Publication \# 7873, 1965).

206. United Nations, The International Bill of Human Rights 1 (U.N. Dept. of Public Information, 1988).

207. See Hurst Hannum, The Status of the Universal Declaration of Human Rights in National and International Law, 25 GA. J. INT'L \& COMP. L. 287, $317-39$ (1995/1996). Hannum concludes that although there is insufficient international support to find that the entire Declaration constitutes binding customary international law, there would seem to be little argument that many provisions of the Declaration today do reflect customary international law. Id.

208. See Restatement of Foreign Relations Law, supra note 141, at $\$ 213$ note 7 (describing voluntary codes of conduct and concluding: "Such codes ... may contribute to the development of international norms supporting state regulation of [multinational] enterprises.") 
VI.

ENFORCEMENT: DOMESTIC AND INTERNATIONAL

There is no dispute about governmental authority to regulate corporations and to require that corporations abide by the rule of law. In fact, given corporate unwillingness to accept social obligations as part of the business ethic, governmental regulation is essential. Domestic legal regimes include myriad rules applicable to corporations and enforceable through the national legal systems. In addition, the international community has developed a considerable body of rules applicable to corporations. These international norms have the advantage of uniformity and consistency. Where domestic norms vary, multinational corporations have the ability to structure their operations so as to take advantage of the most favorable legal regime.

Many international norms are already well-developed; effective enforcement of those rules, however, remains the crucial missing piece of the regulatory puzzle. A great deal of effort has been spent developing enforceable rules to govern the economic behavior of multinational corporations: trade, patents, investment, financing are all the subject of existing international regulation or ongoing efforts to draft rules. These economic regulatory systems include wellelaborated enforcement mechanisms. Ironically, the human rights consequences of multinational corporate operations have received much less international attention, despite the fact that transnationals have an ongoing, and at times devastating, impact on human rights around the world. ${ }^{209}$

Uniform international norms prevent multinational corporations from evading regulation by transferring their operations to countries with weaker standards. Similarly, consistent international enforcement mechanisms would prevent multinationals from evading the consequences of their actions by avoiding nations with the most effective enforcement mechanisms. Such international efforts, however, are at the moment a rather distant goal. In the meantime, domestic enforcement can be at least partially effective, by enforcing either domestic laws or international norms. To the extent that enforcement becomes more widespread, evasive techniques will be correspondingly less successful.

\section{A. An Overview of Domestic Enforcement}

Domestic enforcement can take place either in the home state, the state of citizenship of the corporation, or in the host state, the place in which the relevant operations take place. Host state enforcement has seemingly clear advantages, because it permits local control over local events. Such enforcement is not possible, however, if the host government is complicit in the human rights abuses, as in Burma or Nigeria under the former military dictatorship. Moreover, the

209. As stated by Orentlicher and Gelatt:

The powerful influence of transnational corporations on human rights conditions in the countries where they invest makes it both appropriate, and necessary, to assure that the behavior of these private actors comports with the human rights standards established by public international law and enforced by national law.

Orentlicher \& Gelatt, supra note 98 , at 69. 
unequal division of economic power within the global economy makes such regulation difficult for developing nations. Unequal bargaining power makes it difficult if not impossible for host countries to enforce restrictions on corporate activity. In addition, transnational businesses can often insulate themselves from liability in any one country by moving assets and operations to more favorable locations.

Although home country enforcement has disadvantages, it may nevertheless be a more viable alternative in many situations. Home state enforcement efforts may provoke opposition from host states, arguing that western efforts to impose higher labor and environmental standards will cost them jobs. These considerations may be valid in some settings. Moreover, regulation by the United States is often suspect, given the well-grounded suspicion that the U.S. only intervenes when such regulation is in the self-interest of the U.S. economy. Nevertheless, given the lack of an effective international regulatory system and the difficulties host countries face when trying to impose standards on the corporations acting within their territory, home country regulation may be the best short-term alternative. As Professor Vagts has said, a U.S. refusal to control the activities of U.S. corporations abroad would amount to "abdication" of a power that no other entity can, at this time, exercise. ${ }^{210} \mathrm{He}$ called for U.S. regulation in order to avoid a vacuum in which multinational corporations set their own rules, "without regard to their broader impact."211

Most legal systems assert jurisdiction over the activities of corporations based in their state, although many may either refuse jurisdiction where the activities at issue occurred in another country or apply the laws of that country to the claim. ${ }^{212}$ The United States is more assertive, both in retaining jurisdiction over claims arising in another state and in applying substantive U.S. law to the activities of U.S. corporations in foreign countries. U.S. law permits Congress to impose its authority outside our borders but presumes that statutes do not have extraterritorial effect unless that presumption is overcome by a showing of congressional intent. ${ }^{213}$ Jonathan Turley demonstrates the inconsistent manner in which this supposed presumption is applied: statutes regulating anti-trust, securities and criminal law have been found to apply extraterritorially, while statutes with near identical language in the areas of environmental or labor regulation have been denied extraterritorial application. ${ }^{214}$ Nevertheless, the

210. Vagts, supra note 57 , at 786.

211. Id.

212. Stephens, Translating Filártiga, supra note 128 (manuscript at 24-27, 36-39).

213. EEOC v. Arabian Am. Oil Co., 499 U.S. 244, 248 (1991) (Congress "legislates against the backdrop of the presumption against extraterritoriality," which can be overcome by "the affirmative intention of Congress clearly expressed.").

214. See Jonathan Turley, "When in Rome": Multinational Misconduct and the Presumption Against Territoriality, 84 NW. U. L. REv. 598 (1990). Turley suggests that extraterritoriality is upheld in areas involving protection of the free market, and rejected in cases involving non-market concerns. Id. at 601 . More recently, Gibney and Emerick propose an even more blatant predictor of these otherwise inconsistent decisions: statutes are held to be extraterritorial when to do so would advance U.S. interests, and denied extraterritorial application when against our interests. See Mark Gibney \& R. David Emerick, The Extraterritorial Application of United States Law and the Protec- 
power of the U.S. government to develop norms governing human rights-related behavior, and to impose those norms on corporations based in the United States, is clear.

A bill introduced into the U.S. Congress last year would have imposed a detailed set of international environmental, labor and human rights standards on U.S.-based corporations, with violators facing denial of access to a series of key government trade programs. ${ }^{215}$ The European Parliament has also proposed imposing binding norms on European-based corporations. ${ }^{216}$

Norms governing corporate operations can also be enforced through litigation. A U.S. corporation, for example, can be sued in the United States by individuals harmed by its activities abroad. Such suits have been filed in England, Canada and Australia, asserting negligence claims arising out of corporate activities in foreign countries, where the firm is incorporated in the forum or has taken key decisions in its headquarters. ${ }^{217}$ Such claims are possible only if the litigation satisfies the requirements of the domestic legal system. ${ }^{218}$ The first hurdle is identifying a tort subject to suit. Claims based on domestic tort law are possible only when they fall within recognized domestic causes of action. Given that choice-of-law principles in most legal systems will direct the court to apply the law of the place where the events took place, host state laws may make it difficult or impossible to litigate claims based on human rights violations, labor rights or environmental norms. ${ }^{219}$

The national courts must also be authorized to assert personal jurisdiction over the defendant corporation. Where the forum state is the place of incorporation, that is, the state of nationality of the corporation, personal jurisdiction is generally not a problem. More difficult jurisdictional issues arise where the defendant is the parent company of the corporation charged with the abuses or related in some other way through the corporate group, an issue discussed later in this part.

Dismissal based on forum non conveniens is also a possibility, where all relevant events have taken place outside of the forum territory. However, in England, the House of Lords recently rejected an effort to dismiss a series of

tion of Human Rights: Holding Multinational Corporations to Domestic and International Standards, 10 TeMP. INT'L \& Comp. L.J. 123 (1996).

In our view, the case law falls together very neatly, depending not so much on what will promote a general principle such as the free market, but simply on what will benefit the United States... . In short, the law has been applied extraterritorially when it seeks to prevent negative phenomena from occurring in the United States, but generally not when an agent of the United States (or the government itself) pursues activities that might bring about "negative effects" in other countries.

Id. at 141.

215. The Transparency and Responsibility for U.S. Trade Health Act of 2001, H.R. 460, 107th Cong. (2001).

216. Resolution on EU Standards for European Enterprises Operating in Developing Countries:

Towards a European Code of Conduct, Eur. PARL. Doc. (Com 104) 108 (1999).

217. See Richard Meeran, Accountability of Transnationals for Human Rights Abuses, 148 NEw

L.J. 1686 (Nov. 13, 1998), 148 New L.J. 1706 (Nov. 20, 1998).

218. See generally Stephens, Translating Filártiga, supra note 128.

219. Id. (manuscript at 36-39). 
cases in favor of a forum in South Africa. ${ }^{220}$ The Court found that South Africa did not offer a viable alternative forum given that the plaintiffs would be unable to find counsel capable of handling their claims. The Lubbe litigation is a significant example of a growing recognition by host states that their interests and those of their citizens may be served by litigation in the home states. Indeed, one reaction to such litigation is to argue that citizens of the developing world have a right to bring their claims in the more highly developed legal systems where the corporate defendants are based and where those defendants' assets are available for satisfaction of an eventual judgment. In Lubbe, the South African government supported the plaintiffs' efforts to maintain the lawsuit in England, arguing that South Africa's overtaxed, post-apartheid judiciary was not yet capable of handling such claims. ${ }^{221}$ Similarly, although the government of Ecuador took varying positions as to litigation against Texaco for environmental damage, it eventually argued that the claims should be litigated in the United States. ${ }^{222}$

\section{B. U.S. Human Rights Litigation}

Domestic litigation can also, in some circumstances, apply international law to corporate violations. Many legal systems will not recognize civil international claims in the absence of authorizing legislation. Both civil and criminal claims for violations of fundamental rights, however, may be permitted under the authorization of universal jurisdiction. ${ }^{223}$

Civil claims for human rights violations are possible in the United States because of a unique statute that permits domestic litigation to enforce international law. The Alien Tort Claims Act ${ }^{224}$ grants the federal courts jurisdiction over a "civil action by an alien for a tort only, committed in violation of the law of nations or by a treaty of the United States." In the first modern case to apply the statute, Filartiga v. Peña-Irala, ${ }^{225}$ the Second Circuit held that the statute addresses violations of the law of nations as that body of law evolves over time and concluded that torture by a state of its own citizens violated modern norms of international law. ${ }^{226}$ Since Filártiga, the statute has been consistently inter-

220. Lubbe v. Cape plc, 4 All E.R. 268 (2000).

221. See Statement of Case on Behalf of the Republic of South Africa (May 26, 2000) in Lubbe $v$. Cape plc, supra note 220 (arguing that consideration of "public interest" weighed in favor of deciding the case in England, not in South Africa) (copy on file with author).

222. See Jota v. Texaco, Inc., 57 F.3d 153, 156-58 (2d Cir. 1998), for discussion of the various Ecuadoran government submissions. One Ecuadoran legislator concluded that the United States represented the only possibility of "finding just treatment" for those injured by the oil company's operations. Id. at 157.

223. See Stephens, Translating Filártiga, supra note 128 (manuscript at 46-65).

224. 28 U.S.C. $\S 1350$ (1994) [hereinafter ATCA].

225. Filartiga v. Peña-Irala, 630 F.2d 876 (2d Cir. 1980). Although cited in an early opinion by the U.S. attorney general, 1 OP. ATT'Y GEN. 57 (1795) (in response to complaint that U.S. citizens had attacked a British colony in Sierra Leone, attorney general suggested that those injured file civil suit for damages under ATCA), the statute was largely ignored until the Second Circuit decided the Filártiga case in 1980.

226. Id at $881,884-85$. In Filartiga, the family of a young Paraguayan man who was tortured to death in Paraguay filed a lawsuit against a Paraguayan police officer. The district court dismissed the case, holding that the torture by a state official of that state's own citizen did not violate interna- 
preted as applying to acts that violate "universal, obligatory and definable" norms, ${ }^{227}$ including human rights and humanitarian law violations such as genocide, summary execution, war crimes and crimes against humanity, disappearance, slavery and forced labor. ${ }^{228}$

Two related principles permit ATCA litigation against corporations. First, private corporations are liable for violations of human rights norms such as genocide, slavery and war crimes that by definition apply to private actors as well

tional law, see id. at 880 (summarizing district court decision), the holding was then reversed by the Second Circuit.

227. First articulated in Forti v. Suarez-Mason, 672 F. Supp. 1531, $1539-40$ (N.D. Cal. 1987), this standard has since been widely accepted. See, e.g., Martinez v. City of Los Angeles, 141 F.3d 1373, 1383 (9th Cir. 1998); In re Estate of Marcos Human Rights Litigation, 25 F.3d 1467, 1475 (9th Cir. 1994); Beth Stephens \& Michael Ratner, International Human Rights Litigation IN U.S. CourTs 51-52 (1995).

Filartiga has been followed by every Circuit and District Court to reach a decision on the issue. See, e.g., Wiwa v. Royal Dutch Petroleum Co., 226 F.3d 88 (2d Cir. 2000), cert. denied, 121 S.Ct. 1402 (2001); Beanal v. Freeport-McMoran, Inc., 197 F.3d 161 (5th Cir. 1999); Martinez v. City of Los Angeles, 141 F.3d 1373 (9th Cir. 1998); Hilao v. Estate of Marcos, 103 F.3d 789 (9th Cir. 1996); Kadic v. Karadzic, 70 F.3d 232 (2d Cir. 1995), cert. denied, 518 U.S. 1005 (1996); AbebeJira v. Negewo, 72 F.3d 844 (11th Cir. 1996), cert. denied, 519 U.S. 830 (1996). In one decision by the D.C. Circuit, a three-judge panel rejected an ATCA claim without reaching agreement on the significance of the statute. Tel-Oren v. Libyan Arab Republic, 726 F.2d 774 (D.C. Cir. 1984), cert. denied, 470 U.S. 1003 (1985). One judge disagreed with the Filártiga holding, id. at 798-823 (Bork, J., concurring), while one agreed with it, id. at 775-98 (Edwards, J., concurring), and one would have dismissed the case on the basis of the political question doctrine, id. at 823-27 (Robb, J., concurring).

228. See, e.g., Estate of Marcos, 25 F.3d at 1475-76 (summary execution, torture, disappearance); Kadic, 70 F.3d at 246 (genocide, war crimes, and crimes against humanity); Abebe-Jira, 72 F.3d 844 (torture); Doe I v. Unocal Corp., 963 F. Supp. 880, $891-92$ (C.D. Cal. 1997) (slavery and forced labor).

Claims have been rejected where the courts find no universal consensus as to the prohibition, including claims against private corporations for environmental harm, and claims based on expropriation of property, state contract law, fraud and free speech violations. See, e.g., Beanal v. FreeportMcMoran, Inc., 197 F.3d 161, 166-67 (5th Cir. 1999) (rejecting environmental claim against corporation); Bigio v. Coco Cola Co., 239 F.3d 440, 447-50 (2d Cir. 2000) (rejecting ATCA jurisdiction over claim that defendant acquired property that had previously been expropriated by Egyptian government on basis of the owners' religion); Nat'l Coalition Gov't of the Union of Burma v. Unocal, 176 F.R.D. 329, 345 (C.D. Cal. 1997) (dismissing ATCA claim for loss of property); Wong-Opasi v. Tennessee State University, 229 F.3d 1155 (6th Cir. 2000), available at 2000 WL 1182827 at *2 (unpublished disposition) (rejecting ATCA jurisdiction over state law contract and tort claims); Hamid v. Price Waterhouse, 51 F.3d 1411, 1417-18 (9th Cir. 1994) (holding that claims of fraud, breach of fiduciary duty, and misappropriation of funds are not breaches of the "law of nations" for purposes of jurisdiction under the Alien Tort Statute); Guinto v. Marcos, 654 F. Supp. 276, 280 (S.D. Cal. 1986) ("violation of the First Amendment right of free speech does not rise to the level of such universally recognized rights and so does not constitute a 'law of nations'").

Post-Filártiga cases have recognized additionally the categories of defendants who can be held liable under the ATCA. Filártiga held liable the actual torturer. Defendants in several subsequent cases have included military commanders held responsible for violations committed by troops under their command. Philippine dictator Ferdinand Marcos, for example, was held responsible for thousands of executions, disappearances and torture committed by his military forces. Estate of Marcos, 25 F.3d 1467. See also, e.g., Kadic, 70 F.3d 232 (leader of the Bosnian Serbs held responsible for violations committed by troops); Xuncax v. Gramajo, 886 F. Supp. 162 (D. Mass. 1995) (military commander held responsible for violations committed by troops); Paul v. Avril, $812 \mathrm{~F}$. Supp. 207 (S.D. Fla. 1993) (same); Forti, 672 F. Supp. 1531 (same). 
as official government agents. ${ }^{229}$ Second, private corporations can be held liable for human rights violations when they act together with public officials. ${ }^{230}$

The concept of private corporate liability under the ATCA has been upheld in a handful of preliminary decisions, although none has resulted in a final judgment. In Doe I v. Unocal Corp. ${ }^{231}$ for example, the district court found that a corporation can be held liable for private acts of slavery and forced labor, because the international law prohibitions apply to all actors. Similarly, Beanal $v$. Freeport ${ }^{232}$ found that a private corporation can be held liable for genocide, which by definition is barred whether committed by "public officials or private individuals." 233 These decisions have also recognized that corporations can be held responsible under the ATCA for international law violations that require state action, such as torture and summary executions. As stated by the court in Beanal, "[A] corporation found to be a state actor can be held responsible for human rights abuses which violate international customary law."234 State action will be found when the private corporation acts in complicity with state actors; the courts apply the well developed standards of domestic civil rights cases to determine complicity. ${ }^{235}$

Where litigation is based on international norms, rather than domestic tort law, U.S. courts have found a heightened U.S. interest in offering a forum for the claims. Considering both the ATCA and a more recent U.S. statute, the Torture Victim Protection Act, ${ }^{236}$ the court in Wiwa v. Royal Dutch Petroleum Company found that "Congress has expressed a policy of U.S. law favoring the adjudication of such suits in U.S. courts." ${ }^{237}$ A coordinated international effort to provide access to national courts to litigate human rights claims would greatly further efforts to enforce the human rights obligations of transnational corporations.

229. The Second Circuit decision in Kadic v. Karadzic, 70 F.3d 232, addressed the responsibility of nonstate actors, rather than those committed by officials of recognized states. Kadic involved claims of genocide, torture and war crimes against Radovan Karadzic, the head of the unrecognized Bosnian Serb regime. The court held that the international prohibitions against genocide and certain war crimes apply to all actors, including private citizens. Id. at 241-43.

230. The Kadic court also found that international law norms that govern official action apply to private actors who act "in concert with" a state. $I d$. at 245. Plaintiffs alleged that Karadzic acted in concert with the recognized government of the former Yugoslavia.

231. 963 F. Supp. 880, 891-92 (C.D. Cal. 1997), dismissed on a motion for summary judgment, 110 F. Supp. 2d 1294 (C.D. Cal. 2000) (appeal pending).

232. Beanal v. Freeport-McMoran, Inc., 969 F. Supp. 362, $372-73$ (E.D. La. 1997). In Beanal, however, the district court dismissed plaintiff's third amended complaint, holding that even as amended it still did not adequately allege genocide. Beanal v. Freeport-McMoran, Inc., 1998 WL 92246 (E.D. La. Mar. 3, 1998) (unpublished opinion), aff'd 197 F.3d 161 (5th Cir. 1999).

233. Genocide Convention, supra note 140 , art. 4.

234. Beanal, 969 F. Supp. at 376.

235. See, e.g., Kadic, 70 F.3d at 245; Beanal, 969 F. Supp. at 374-80; Doe I v. Unocal, 963 F. Supp. at $890-91$.

236. Torture Victim Protection Act of 1991, 28 § U.S.C. 1350 note (1994).

237. Wiwa v. Royal Dutch Petroleum Co., 226 F.3d 88, 106 (2d Cir. 2000), cert. denied, 121 S.Ct. $1402(2001)$. 


\section{Extraterritorial Jurisdiction and Enterprise Theory}

The Wiwa claims against Royal Dutch Petroleum illustrate a final obstacle to the use of domestic court systems to hold transnational corporations accountable. As stressed earlier, national law is ill-structured to regulate multinationals, whose operations, by definition, straddle many countries. Domestic judicial systems may be unable to obtain jurisdiction over the piece of the multinational that actually sets human rights policies and that has the resources to satisfy a judgment. In Wiwa, a magistrate originally concluded that the U.S. federal court in New York did not have jurisdiction over Royal Dutch Petroleum. ${ }^{238}$ The district court judge disagreed, finding jurisdiction, a holding that was upheld by the Second Circuit on appeal. ${ }^{239}$ However, jurisdiction was based not upon the presence of Shell gas stations throughout the United States; the court did not consider plaintiffs' argument that Shell U.S.A. was the alter ego of Royal Dutch Petroleum. ${ }^{240}$ Jurisdiction instead was premised on a handful of direct contacts between Royal Dutch and New York State. The Shell components clearly have put tremendous effort into structuring their operations in such a way as to isolate themselves from the responsibilities of the other members of their corporate family - an effort that might have worked but for the direct contacts between the parent company and New York.

This same problem arises when applying international rules of jurisdiction. International law sets guidelines for exercise by national legal systems of both jurisdiction to prescribe, to determine the rules applicable to persons or activities, and jurisdiction to adjudicate, to subject persons or things to judicial process. ${ }^{241}$ Both jurisdiction to prescribe and to adjudicate generally turn upon the contacts with the state seeking to assert jurisdiction. ${ }^{242}$ Home state jurisdiction over multinational corporations is based upon the nationality of the corporation, that is, the fact that it is incorporated in the home state. However, where a multinational corporation is composed of multiple units, each incorporated in different states, each of these units may have a different "home state." As a result, multinational corporations argue that parents and subsidiaries are not subject to the jurisdiction of the other's home state. Once again, the reality of economic interdependence is masked by the legal fiction of separate corporate identities.

This highlights the importance of Professor Blumberg's call for application of enterprise law, looking at the reality of control, decision-making and economic benefit rather than the formalities of corporate legal structures. Blumberg highlights an emerging view of the corporate nature, one that recognizes that

238. Id. at 94 .

239. Id. at $94-99$.

240. Id. at 95 n.4.

241. Restatement of Foreign Relations Law, supra note 141, $\$ 401$ (defining categories of jurisdiction under international law).

242. Both look at the location of the persons, things or activities central to the dispute; the nationality of the natural or legal persons involved; and the impact of the activities at issue on the state. See id. $\S \S 402$ (listing bases of jurisdiction to prescribe), 421 (listing bases of jurisdiction to adjudicate). 
corporations are no longer single-nation entities with a readily identifiable nationality:

These very large corporations typically operate as multi-tiered multinational groups of parent and subsidiary corporations collectively conducting worldwide economically integrated enterprises that for legal or political purposes have been fragmented among the constituent companies of the group. In selected areas, the law is beginning to recognize corporate groups rather than a particular subsidiary company, as the juridical unit, and to impose group obligations and, less frequently, to recognize group rights as well. ${ }^{243}$

Such an approach was tried-and rejected-in response to the Union Carbide disaster in Bhopal, India, after a chemical leak in 1984 killed thousands of people and injured tens of thousands more. ${ }^{244}$ The government of India, representing those injured by the chemical leak, argued in U.S. federal court that the multinational corporation must be viewed as "one entity" rather than as independent parts:

In reality there is but one entity, the monolithic multinational, which is responsible for the design, development and dissemination of information and technology worldwide, acting through a neatly designed network of interlocking directors, common operating systems, global distribution and marketing systems, financial and other controls. ... Persons harmed by the acts of [a] multinational corporation are [not] in a position to isolate which unit of the enterprise caused the harm, yet it is evident that the multinational enterprise that caused the harm is liable for such harm. The defendant multinational corporation has to bear this responsibility for it alone had at all material times the means to know and guard against hazards likely to be caused by the operation of the said plant, designed and installed or caused to be installed by it and to provide warnings of potential hazards. 245

The district court flatly rejected this approach, dismissing the case on the basis of forum non conveniens, after concluding that there was insufficient connection between the U.S. parent company and the Indian operation to justify suit in U.S. courts.

Shortly after the Bhopal disaster, Westbrook noted the difficulty in applying notions of enterprise liability to an economic system built upon limiting liability:

[A] central theme of the last two centuries of modern economic development has been the effort to harness enterprise capitalism without crushing it. . . . To choose to adopt or reject a theory of enterprise liability for personal injuries, or at least for mass disasters, is to confront once again the dilemma of capitalism. ${ }^{246}$

The concept of limited liability, however, arose long before corporations were permitted to expand to create the interlocking multinational enterprises that now dominate the international economy. As the Bhopal litigation illustrates, in the

243. Blumberg, supra note 83 , at 298 (footnotes omitted).

244. See Jamie Cassels, Outlaws: Multinational Corporations and Catastrophic Law, 31 CuMB.

L. REv. 311 (2000), for a summary of the facts and efforts to obtain legal redress.

245. Id. at 324 (quoting Complaint, Union of India v. Union Carbide Corporation (5 Sept., 1986), II 19). The full complaint is reprinted in Valiant Victims and Lethal Litigation: THE Bhopal Case 3 (Upendra Baxi and Amita Dhanda eds., 1990).

246. Jay Lawrence Westbrook, Theories of Parent Company Liability and the Prospects for an International Settlement, 20 TEx. INT'L L. J. 321,326 (1985). 
absence of a pragmatic international approach, one that recognizes the reality of economic interdependence rather than relying on legal independence, multinationals will continue to evade regulation in domestic legal systems. International regulation and enforcement are necessary to regulate an international enterprise. To be fully effective, the corporate regulatory system must recognize enterprise principles so that it can deal with the global phenomenon of multinational corporations.

\section{VII.}

\section{CONCLUSION}

Multinational corporations are the driving force behind the global economy. Reining in their unchecked power, imposing regulations that force accountability for human rights abuses, is indeed a challenge to modern capitalism. International law has already developed applicable standards. The task ahead is to find effective mechanisms to enforce those norms, to ensure that the amorality of profit does not permit corporate human rights abuses to fester for another fifty years. 